\title{
Will Strangers Help you Enter? The Effect of Foreign Bank Presence on New Firm Entry
}

\author{
Theodora Bermpei ${ }^{1,2}$ • Antonios Nikolaos Kalyvas ${ }^{3,4}$ • \\ Lorenzo Neri ${ }^{3,5}$ - Antonella Russo ${ }^{3}$
}

\begin{abstract}
We examine the effect of foreign bank presence on new firm entry in 83 economies over the 2005-2013 period. The empirical findings show that foreign bank presence exerts a positive and significant effect on firm entry. This effect subsides in countries with strong creditor rights, while it strengthens in economies with high depth of credit information sharing. In further analysis, we find that the type of credit information sharing provider matters. The positive effect of foreign bank presence on firm entry strengthens in the presence of a private credit bureau, whereas it is subdued in the presence of a public credit registry. Finally, we find some evidence that cultural and information sharing distance between home and host econo-mies weakens the positive effect of foreign bank presence on firm entry. In terms of policy, attracting foreign banks while strengthening credit information sharing through private credit bureaus could benefit entrepreneurship in host economies.
\end{abstract}

Antonios Nikolaos Kalyvas

n.a.kalyvas@ southampton.ac.uk

Theodora Bermpei

t.bermpei@essex.ac.uk

Lorenzo Neri

1.neri@bbk.ac.uk

Antonella Russo

a.russo@greenwich.ac.uk

1 University of Nottingham Trent, Burton Street, Nottingham NG1 4BU, UK

2 Finance Centre, University of Essex, Wivenhoe Park, Colchester CO4 3SQ, UK

3 University of Greenwich, Old Royal Naval College, Park Row, London SE10 9LS, UK

4 Department of Banking and Finance, University of Southampton, Building 2, 12 University Rd, Southampton SO17 1BJ, UK

5 Department of Management, Birkbeck, University of London, Malet Street, Bloomsbury, London WC1E 7HX, UK 
Keywords Foreign banks · Firm entry $\cdot$ Creditor rights $\cdot$ Information sharing

JEL Classification $\mathrm{G} 21 \cdot \mathrm{F} 23 \cdot \mathrm{L} 26$

\section{Introduction}

The globalization of business is a major feature of the global economy. The banking sector is not an exception to this trend. Claessens and Van Horen (2014a, 2015) show a growing presence of foreign banks in most economies from 1995 to 2013. As a result, academics and policy makers are keen to investigate the effect of foreign banks on the performance of the banking sector and on credit allocation in the host economies. This paper relates to the latter strand of the foreign banking literature as it examines the effect of foreign bank presence on entrepreneurship in a cross-country empirical framework. In essence, we attempt to answer the question: Does foreign bank presence promote or inhibit new firm entry?

This question is of importance given the increase in foreign bank presence worldwide and the benefits of entrepreneurship for development. Entrepreneurship is a key contributor to the economic growth and dynamism of a country (Caves 1998; Bartelsman et al. 2004). It could increase competition (Cohen and Klepper 1992); the transfer of resources from low to high productivity activities (Bartelsman et al. 2003) and the generation, dissemination and application of innovative ideas that enhance firm productivity (Nickell 1996). Furthermore, entrepreneurship decreases the unemployment rate (Branstetter et al. 2014; Siemer 2014). These benefits of entrepreneurship have induced policymakers, especially in the aftermath of the crisis, to place policies that encourage new firm creation in the top of their agenda (Klapper and Love 2011a).

Given the significance of entrepreneurship in the policy agenda, there is a burgeoning research on the determinants of cross-country heterogeneity in the rate of new firm entry (Djankov et al. 2002; Klapper et al. 2006; Bruno et al. 2013; Ardagna and Lusardi 2010; Da Rin et al. 2011; Klapper and Love 2014; Klapper et al. 2015). These studies concentrate on the effect of business regulations such as entry regulation and taxation as well institutional quality on new firm entry. Most of this research employs access to finance as a control variable, usually proxied by the level of financial development, and find that it has a positive association with entrepreneurship. Another strand of the literature relates explicitly to the effect of the structure of the financial industry on new firm entry (Cetorelli and Strahan 2006; Bonaccorsi di Patti and Dell'Ariccia 2004; Aghion et al. 2007). These studies find that more competition in the banking industry, as well as a higher level of private credit, has a positive effect on new firm entry. Thus, there is a consensus in the literature that financing conditions matter for entrepreneurship. However, the presence of foreign banks, an important aspect of crosscountry variation in financing conditions, has not been adequately examined with regards to its impact on entrepreneurship rates. ${ }^{1}$

\footnotetext{
${ }^{1}$ To the best our knowledge there is only one study (Havrylchyk 2012) that examines the impact of foreign bank presence on entrepreneurship for a sample of transition economies over the 2000-2005. However, there are some important differences between this paper and ours. The study of Havrylchyk (2012) focuses on few transition economies, whereas our paper uses a global sample of 83 economies. Secondly, we utilize the recent foreign bank ownership dataset of Claessens and van Horen (2014a, 2015). This dataset represent the most diligent effort to measure accurately cross-country foreign bank presence. Thirdly and more importantly, our study takes into account conditioning effects due to important institutional arrangements (creditor rights and credit information sharing) that aim to alleviate the information asymmetry between banks and candidate borrowers. Finally, the study of Havrylchyk (2012) is for the 2000-2005 period while the timeline of our study (2005-2013) is wider and also includes the crisis and some of the post-crisis period.
} 
The extant literature on the effect of foreign banks' presence on access to firm credit points into two directions. This first is that foreign banks due to geographic and cultural distance constraints (Mian 2006), their hierarchical structure (Stein 2002) and their reliance on lending technologies that depend on "hard" financial information (Beck et al. 2016) face a high degree of information asymmetry especially vis-à-vis small, young and opaque domestic borrowers. In line with this direction, a stream of studies finds that foreign bank presence benefits the access to finance for borrowers that are foreign, large and more transparent (Detragiache et al. 2008; Brown et al. 2011; Pennathur and Vishwasrao 2014). The second is that foreign banks have developed advanced lending technologies, such as credit scoring as well as leasing and asset-based lending, designed to serve opaque domestic borrowers (Berger and Udell 2006; De Haas and Naaborg 2006; De la Torre et al. 2010). Therefore, foreign banks could overcome the information asymmetries between them and opaque borrowers and thus improve access to credit for the latter. Furthermore, foreign banks could benefit access to credit for opaque borrowers indirectly by forcing domestic banks to shift their credit portfolios towards the latter (Degryse et al. 2012). A stream of studies provides empirical evidence that foreign bank presence improves the access to finance also for smaller, opaque and young firms (Clarke et al. 2002; Beck et al. 2004; Berger et al. 2004; Gianetti and Ongena 2012).

The above findings although inconclusive point to a common element: the effect of foreign banks on access to credit for opaque domestic borrowers largely depends on the interplay between the information asymmetries they face in the host economy and the competitive advantages they possess in terms of lending technology that would enable them to overcome such information asymmetries. Since candidate new firm entrants are one of the most informationally opaque credit market segments because of the absence of historical records of their performance (Bulan and Yan 2009; Chavis et al. 2011), the information asymmetries between them and foreign banks could be particularly high. This, in combination with the fact that most studies that examine the effect of foreign bank presence on access to credit are inconclusive and focus on existing firms, justifies an empirical analysis with regard to the effect of foreign bank presence on new firm entry.

It is also interesting to investigate the existence of conditioning effects with respect to the effect of foreign bank presence on entrepreneurship. Claessens and Van Horen (2014a) show that the effect of foreign banks on private credit depends largely on host country institutional characteristics. Therefore, we opt to examine for conditioning effects of characteristics that relate to the information asymmetry that foreign banks face in host economies especially in terms of the opaque borrower segments such as the market for entrepreneurial credit. Such conditioning effects could stem from the level of credit information sharing and creditor rights in the host economy. These are institutional arrangements that aim to alleviate the information asymmetry between creditors and borrowers (Jappelli and Pagano 2002; Dell'Ariccia and Marquez 2006; Doblas-Madrid and Minetti 2012). Credit information sharing, by providing historical data on the past behavior of borrowers, could enable loan screening and thus reduce information asymmetry issues between banks and borrowers (Kallberg and Udell 2003; Dierkes et al. 2013). Therefore, credit information sharing could serve as a proxy for the information asymmetry level that foreign banks face in host economies. Additionally, although information on candidate new firm entrants 
does not yet exist in the credit registries, information on their aspiring owners does. This could enable foreign banks to use the advanced lending technologies, such as credit scoring models, that they usually employ in order to serve the most opaque credit market segments, also in the market for entrepreneurial credit (Berger and Udell 2002; Berger and Udell 2006). Creditor rights, by facilitating the use of collateral, could also reduce information asymmetry by enabling banks to screen borrowers efficiently (Bester 1985; Berger et al. 2011). This could be useful for foreign banks in the market of entrepreneurial credit because entrepreneurs could post personal assets as collateral in order to obtain bank credit (Robb and Robinson 2013). Based on the above, the second question we attempt to answer in this study is the following: Do creditor rights and information sharing condition the effect of foreign bank presence on new firm entry?

We employ a dataset of 83 economies over the 2005-2013 period and find, by using fixed-effects, dynamic panel, instrumental variables (IV) and panel vector auto regression (VAR) models, that foreign bank presence exerts a positive and significant effect on new firm entry. This is in accordance with studies that find that foreign bank presence could improve the access to credit for opaque domestic borrowers either directly through the employment of advanced foreign bank lending technologies (De Haas and Naaborg 2006) or indirectly by incentivising domestic banks to serve the latter (Gianetti and Ongena 2012). ${ }^{2}$ Furthermore, we find some evidence that the positive effect of foreign bank presence on entrepreneurship strengthens in countries with higher levels of depth of credit information sharing. This could denote that credit information sharing could empower the lending technologies that foreign banks tend to rely on when they extend credit to opaque domestic borrowers (Beck et al. 2011; Beck et al. 2016). We also find that the positive effect of foreign bank presence on new firm entry subdues at higher levels of creditor rights. This result lends support to the findings of Bruno and Hauswald (2014) that foreign banks possess an advantage in debt contract enforcement in countries with weak legal structures.

In further analysis, we find that the positive effect of foreign bank presence subdues at the presence of a public credit registry, while it strengthens when a private credit bureau is in place. These results could stem from the fact that these two types of credit registries differ significantly in the availability of credit information history they contain (OECD 2010; World Bank 2014). Finally, we also provide some evidence that cultural proximity between the home and host economies strengthens the positive effect of foreign bank presence on entrepreneurship, while distance in terms of information sharing weakens this effect. This shows that distance constraints do not operate only through geographic and cultural factors (Mian 2006), but also through institutional factors that determine the level of the information asymmetry disadvantage foreign banks face in host economies.

These findings contribute to the literature in three ways. Firstly, we add to the entrepreneurship determinants literature (e.g. Djankov et al. 2002; Klapper et al. 2015; Belitski et al. 2016) and specifically to the literature that relates financing conditions to new firm formation (e.g. Aghion et al. 2007; Havrylchyk 2012). Secondly, we add

\footnotetext{
${ }^{2}$ The analysis in this paper highlights the possible channels through which foreign bank presence could affect new firm entry. However, the use country-level data (i.e. we do not observe bank-firm relationships) renders beyond the scope of this paper to evaluate if new firm entrants could benefit directly from foreign bank lending or indirectly because foreign bank presence could alter the lending policies of domestic banks.
} 
to the literature that examines the effects of foreign banks on the real economy of the host countries (e.g. De Haas and Van Lelyveld 2006; Gianetti and Ongena 2012; Bruno and Hauswald 2014). Finally, we also add to the literature that investigates the effects of creditor rights and information sharing on firm credit (e.g. Brown et al. 2009; Grajzl and Laptieva 2016; Love et al. 2016).

The rest of the paper is structured as follows: section 2 presents some theoretical considerations and develops hypotheses, sections 3 and 4 present the data and the methods respectively, section 5 reports and discusses the results, whilst the final section offers some concluding comments together with some policy implications.

\section{Theoretical considerations and hypotheses development}

\subsection{The effect of foreign bank presence on new firm entry}

According to the "home advantage" hypothesis of Berger et al. (2000) foreign banks operate less efficiently than domestic banks because the former face high "liability of foreignness" in a given host economy. An important component of the "liability of foreignness" that foreign banks face is the high level of information asymmetry between them and domestic borrowers. This could be attributed to two sources. The first relates to the distance constraints (Mian 2006) that foreign banks face in a given host country. A foreign bank may be headquartered in a very different market environment, with a different language, culture and so forth. This renders costly for foreign banks collecting and processing information on local borrowers. The second source of information asymmetry between foreign banks and local borrowers relates to the hierarchical structure of the former. This renders them less able to put an effort in acquiring "soft" information on local borrowers (Stein 2002; Berger et al. 2005). On the contrary, foreign banks tend to rely on "hard" information on local borrowers. This "hard" information should be credible and publicly verifiable, such as a firm's audited financial accounts (Mian 2006; Berger and Black 2011).

It would be rational then to expect that foreign banks will tend to serve the more transparent domestic firms in the host economy as the theoretical model of Dell'Ariccia and Marquez (2004) predicts. In support of this model, Detragiache et al. (2008) find that foreign banks, by "cherry-picking" the most transparent domestic borrowers, lead to a decline in aggregate credit which disproportionally affects opaque domestic borrowers who find themselves in a worse borrower pool that faces prohibitively high interest rates. In another microeconometric study, Pennathur and Vishwasrao (2014) find that foreign banks prefer to lend to financially transparent firms. Similar findings are evident also in other studies (Berger et al. 2001; Berger et al. 2008; Brown et al. 2011).

The above considerations put less transparent domestic borrowers at a disadvantage in terms of foreign bank financing in comparison with more transparent ones. Potential new firm entrants in a given credit market could be in an even more disadvantaged position from the foreign bank financing standpoint than established (existing) domestic firms because the latter type of firms could cater foreign banks with more "hard" information in comparison with the former. Thus, foreign bank presence, by exacerbating the disadvantage of information provision that potential new firm 
entrants face vis-à-vis existing firms in the host economy, could inhibit new firm entry. Based on the above discussion the first hypothesis (H1.A) is the following:

\section{H1.A: Foreign bank presence decreases new firm entry}

On the other hand, a higher level of foreign bank presence could promote new firm entry in host economies. Berger et al. (2000) introduce also the "global advantage" hypothesis, which posits that foreign banks possess strong competitive advantages, especially in terms of lending and information technologies, in comparison with domestic banks. Thus, foreign banks could overcome the "liability of foreignness" in terms of information asymmetry with opaque borrowers.

Berger and Udell (2006) propose a new paradigm of bank financing to opaque borrowers that involves also foreign bank lending. In their paradigm, foreign banks are able to provide credit to less transparent clients by employing transactional technologies that facilitate arms-length financing. An important such technology is the so-called small business credit scoring. This involves the entry of basic data, also on the personal history of the firm owner, into models that predict future loan performance. This is particularly useful for lending to very opaque firms since for such entities, the creditworthiness of the firm and the owner are closely related (Feldman 1997; Mester 1997). Foreign banks could also employ asset-based lending and leasing in order to extend credit to opaque borrowers. In asset-based lending, the bank looks mainly at the underlying assets as the primary source of repayment while in leasing the leesor (lender) owns an asset and rents it to a leese (Berger and Udell 2006). In support of this paradigm, several studies find that foreign banks, by developing such lending technologies, increase lending to opaque domestic borrowers (Clarke et al. 2005; De Haas and Naaborg 2006; De la Torre et al. 2010).

The paradigm of Berger and Udell (2006) refers to existing firms and not specifically to potential new entrant firms, but it could also apply to the latter. For example, foreign banks, in the absence of firm-specific "hard" information, could obtain such information on the aspiring owner of a new firm and employ credit scoring technologies to predict future loan performance.

This conforms to previous research that finds that banks apply credit scoring models that use as inputs personal information on the owner in order to finance risky opaque firms outside their local market (Frame and Woosley 2004; Berger et al. 2005). The use of assetbased lending by foreign banks could also promote new firm entry. This lending technology, according to Berger and Udell (2006), could use as collateral the personal assets of a firm's owners and thus is compatible with the findings of Robb and Robinson (2013) that entrepreneurs obtain start-up bank financing by posting personal assets as collateral.

There is another potential channel through which higher foreign bank presence could increase new firm entry rates. This is an indirect channel and involves the reaction of domestic banks to higher levels of foreign bank presence. It could be the case that incumbent domestic banks would increase credit supply to opaque local borrowers, such as aspiring new firm entrants, as a reaction to the reduced supply of credit to such borrowers by foreign banks. Gianetti and Ongena (2012) provide microeconometric evidence that foreign banks indirectly promote the access to credit for more opaque borrowers that previously did not have an established bank relationship. This modification in the behavior of domestic banks is one of the explanations given by Clarke et al. (2001) to support their findings that higher foreign bank presence improves the financing conditions of small and less transparent firms. Given that aspiring entrepreneurs form one 
of the least transparent segments of the credit market, domestic banks might be more willing to serve them if they face fierce competition by foreign banks in the transparent segments of the credit market.

Based on the above discussion we formulate the competing to H1.A hypothesis, H1.B, as follows:

\section{H1.B: Foreign bank presence increases new firm entry}

\subsection{The conditioning effects of creditor rights and information sharing}

Creditor rights have the potential to decrease the information asymmetry between lenders and borrowers. In a strong creditor rights environment, banks are able to use collateral requirements to differentiate the risk level of the projects of seemingly comparable loan applicants. This reduction in adverse selection happens through a signaling channel. Candidate borrowers with lower risk projects, and thus lower risk of loan default, post higher levels of collateral that candidate borrowers with higher risk projects would not be willing to post (Besanko and Thakor 1987; Godlewski and Weill 2011). Therefore, strong creditor rights could facilitate the use of collateral as a singling device for banks and thus increase credit towards entrepreneurs. Schmalz et al. (2013) provide microeconometric evidence that the use of personal assets as collateral increases entrepreneurial activity.

The usefulness of collateral in the provision of entrepreneurial credit could be more important for foreign banks than domestic banks. In the theoretical model of Sengupta (2007) foreign banks use the signaling nature of collateral in order to compete successfully with domestic banks. In support of this model, Haselmann et al. (2010) provide empirical evidence that foreign banks increase their lending considerably more than domestic banks after legislative changes that facilitate the use of collateral. Furthermore, some lending technologies, such as asset-based lending, that foreign banks could use in order to provide finance to opaque domestic borrowers depend on the use of collateral (Berger and Udell 2006). Therefore, our second hypothesis is the following:

\section{H2.A: Creditor rights strengthen (moderate) the positive (negative) effect of foreign bank presence on new firm entry.}

However, it could be the case that foreign banks would be more able to promote new firm entry in a lower creditor rights environment. Empirical evidence from Bruno and Hauswald (2014) suggests that foreign banks possess an advantage in debt contract enforcement in an uncertain legal environment. One potential reason could be the development by foreign banks of lending technologies that do not depend on creditor rights, as for example advance credit scoring technologies for opaque business lending (De la Torre et al. 2010). Such lending technologies are based on "hard" information mainly on the owner (or on the aspiring owner in the case of new firm entry) of an opaque firm (Berger and Udell 2006). In this way, foreign banks could assess the creditworthiness of a potential owner of a new firm without relying on the signaling channel that strong creditor rights could facilitate. Additionally, some other lending technologies, such as leasing, that foreign banks could employ in order to 
finance the opaque credit market segment of entrepreneurial credit, do not involve the transfer of asset ownership to the borrower, thus rendering creditor rights less relevant. Furthermore, in a strong creditor rights environment, there could be a shift in the composition of foreign bank credit towards mortgage lending. This shift could render obtaining entrepreneurship credit from foreign banks less probable. In line with this argument, De Haas et al. (2010) find that when foreign banks perceive collateral regulation to be of high quality they focus more on mortgage lending. Based on the above discussion we formulate the competing to H2.A hypothesis as follows:

\section{H2.B: Creditor rights moderate (strengthen) the positive (negative) effect of foreign bank presence on new firm entry.}

Information sharing could reduce the information asymmetry issues that banks face in a credit market by providing them with information about the past behavior borrowers (Pagano and Jappelli 1993). Several studies provide empirical evidence (Kallberg and Udell 2003; Dierkes et al. 2013; Bos et al. 2016) that information sharing reduces adverse selection and leads to efficient loan screening. A lower level of information asymmetries due to credit information sharing could lead to a higher level of private sector credit in an economy (Djankov et al. 2007) especially towards opaque and young firms that cannot directly provide banks with "hard" information such as a lengthy history of audited financial statement accounts (Brown et al. 2009; Martínez Pería and Singh 2014). Thus, information sharing could serve as proxy for the level of information asymmetries between lenders and borrowers in a country especially as far as concerns the opaque credit markets segments such as the market for entrepreneurial credit.

A lower level of information asymmetries in the credit market could be particularly important for foreign banks when they extend credit to opaque domestic borrowers because of the disadvantage of foreign banks in using "soft" borrower information (Gormley 2010). In line with this, Claessens and Van Horen (2014a) find that foreign banks have a negative effect on private credit in countries with limited information sharing. Therefore, a high level of information sharing, by reducing information asymmetries, could alleviate the "cherry picking" behavior of foreign banks and the associated negative effects it could have in the overall extension of credit especially in the opaque segments of the credit market (Detragiache et al. 2008). This could also benefit the access to entrepreneurial credit which is one of the least transparent segments of the credit market.

A mechanism through which the low level of information asymmetries that information sharing facilitates could benefit the provision of entrepreneurial credit by foreign banks is the empowerment of the lending technologies they could employ for such type of lending. Firmspecific information on candidate new firm entrants might not yet exist in the credit registries, but personal information on aspiring entrepreneurs does. This could enable the use of lending technologies, such as credit scoring models that foreign banks could use in order to provide credit to opaque borrowers (De la Torre et al. 2010), also in the market for entrepreneurial credit (Black and Strahan 2002). This conforms to the fact that credit scoring lending technologies for opaque firms tend to rely extensively on "hard" information on the personal history of a firm's owner that banks source from credit bureaus (Berger and Udell 2002; Berger and Frame 2007; Berger et al. 2011). In line with this argument, Beck et al. (2016) provide evidence that the sharing of "hard" information, such as borrower ratings, through the credit 
registry partly eliminates the informational disadvantage of foreign banks when extending loans to opaque borrowers.

Through another channel, increased information sharing could induce foreign banks to increase their provision of credit in the host economy because of the disciplinary effect information sharing have on borrowers (Klein 1992). Information sharing could induce firm managers to perform well in order to avoid a loan default that would blacklist themselves or their firm and as a result, they could be excluded from future bank financing (Padilla and Pagano 1997, 2000). This could also apply in the market for entrepreneurial credit as once aspiring entrepreneurs obtain credit from foreign banks the information on this transaction enters the credit information provider.

Based on the above discussion, we formulate our third hypothesis, H3, as follows:

\section{H3: Information sharing strengthens (moderates) the positive (negative) effect of foreign bank presence on new firm entry.}

\section{Data and methods}

\subsection{Data}

\subsubsection{New firm entry}

The dependent variable of our study is new firm entry density (ENT). This is defined as the number of newly registered companies per 1000 working-age people (ages 15-64) per year. ${ }^{3}$ We source the data on firm entry density from the World Bank Entrepreneurship Database. This database comprises a cross-country, time-series panel dataset of the number of newly formed companies. The dataset is consistent and comparable across heterogeneous legal regimes and economic systems and has been used widely in the recent literature on the determinants of new firm entry (Klapper and Love 2011b; Braunerhjelm and Eklund 2014; Klapper and Love 2014; Klapper et al. 2015; Belitski et al. 2016). For reasons of consistency, data availability, and relevance to high growth entrepreneurship the dataset focuses on limited liability firms (Klapper et al. 2010). Furthermore, this legal form of business is the most prevalent globally (Doing Business 2010). The dataset is available for most economies globally over the 2004-2014 period with a limited number of missing observations. To conform to the previous literature (see for example Klapper and Love 2014), we exclude from our analysis observations from economies that are defined as "offshore financial centers" by the IMF as they might reflect the creation of shell companies and not active firms. Our final dataset, taking into account the availability of the explanatory variables comprises of 632 observations for 83 countries over the 2005-2013 period. The countries that we include in this study are available in Table 7 of the appendix.

\footnotetext{
${ }^{3}$ In robustness checks we also use an alternative measure of entrepreneurship: this is the nascent entrepreneurship sourced from the Global Entrepreneurship Monitor (GEM). We have extensively reviewed the literature on the determinants of new firm entry in a cross-country framework. The new firm entry rate from the World Bank Entrepreneurship Database together with the GEM measure of entrepreneurship are the most commonly employed variables in the literature to capture country-level entrepreneurship.
} 


\subsubsection{Foreign bank presence}

For the foreign bank presence variable, we utilize the bank ownership dataset of Claessens and van Horen (2014a, 2015). There are three major advantages of this dataset. The first is that it provides the specific point in time when a foreign bank entered a host economy. This gives a precise within-country time variation of the foreign bank presence during the period of the study. The second advantage is that Claessens and van Horen (2014a, 2015) consider also some other critical issues such as the exit of a foreign bank from the host economy, mergers and acquisitions and avoidance of double counting. Furthermore, this dataset provides information on the home economy of each foreign bank. The above advantages render the Claessens and van Horen (2014a, 2015) dataset the most comprehensive effort to date in terms of foreign bank presence measurement. In this dataset, a bank is defined as foreign, in accordance with the banking literature, when $50 \%$ or more of the specific bank's equity is owned by foreigners. The authors construct two indices of foreign bank presence. The first is the ratio in each economy of foreign banks over the total number of banks and the second measure is the ratio of foreign-owned bank assets over the total bank assets. In this study, we employ the second ratio, (FBAST), because it provides a better measure of the magnitude of foreign bank presence and is the one that the bank literature employs (Brown et al. 2009; Cull and Martínez Pería 2013; Bruno and Hauswald 2014). ${ }^{4}$

\subsubsection{Creditor rights, information sharing, and control variables}

To account for creditor rights and information sharing at the country level we use the "Getting Credit" category of regulations from the "Doing Business" project of the World Bank. More specifically, we employ the creditor rights index (CR), which measures the extent to which bankruptcy and collateral legislation defends the rights of lenders. This index ranges from 0 to 10 with higher values denoting stronger creditor rights protection. To account for information sharing we use the depth of credit information index (DEPTH). This variable is an indicator for the richness of information related to the scope, coverage and accessibility of the information existing in each country's state-owned credit registry or private credit bureau. The values of this index range from 0 to 6 for each economy and higher values represent higher levels of informational depth. Both of these indices are widely used in the banking literature (Houston et al. 2010; Claessens and Van Horen 2012; Bruno and Hauswald 2014).

The control variables are drawn from the literature on the determinants of firm entry (Da Rin et al. 2011; Klapper and Love 2011b; Bruno et al. 2013; Dreher and Gassebner 2013; Klapper and Love 2014). Firstly, we control for macroeconomic conditions. Thus, in our models, we include GDP growth (GDPgr) to account for economic growth dynamics and business cycles effects (Klapper et al. 2015). We also employ the natural logarithm of GDP per capita in real terms (InGDPcap) in order to control for the general level of economic development (Bruno et al. 2013; Dreher and Gassebner 2013). Additionally, we use the ratio

\footnotetext{
${ }^{4}$ The first ratio, the number of foreign banks divided by the total number of banks in a country, may provide a better measure of foreign bank presence in terms of entry. The two ratios of foreign bank presence are highly correlated (correlation stands at around 0.8 , see Table 8 in appendix) and estimations using either of these two ratios of foreign bank presence produce qualitatively similar results. Therefore, in our main analysis we present the results using the ratio of foreign banks assets over total bank assets (FBAST) as a measure of foreign bank presence. In the robustness checks section of this paper we also present results using the ratio of the number of foreign banks over total banks (FBNUM).
} 
of private sector credit to GDP (PSC) to control for the level of financial development (Klapper et al. 2006; Dreher and Gassebner 2013). Finally, we account for the value added from agriculture as a percentage of GDP (AGRIC) as an alternative proxy for development (Dreher and Gassebner 2013). We source these variables from the World Development Indicators (WDI) of the World Bank.

The second set of control variables are proxies of the regulatory conditions in the host economy. To this end, we use several regulatory variables, relevant for new firm entry, from the "index of economic freedom" of the Heritage Foundation. The various fields of this index range from 0 to 100 with higher values denoting less regulatory burden. In particular, we use the business freedom index (BUSFREE), which measures the ability to start, operate and close a business in an economy. We expect that new firm entry will have a positive association with less regulatory hurdles in establishing a new firm (Klapper et al. 2006; Klapper and Love 2011b). We also use the fiscal freedom index (FISCFREE), which is a measure of the tax burden that the government imposes on the firms and individuals in a given country. Theoretical models (Cullen and Gordon 2007) and empirical evidence (Demirguç-Kunt et al. 2006; Da Rin et al. 2011) suggest that higher taxation deters firm entry.

The government freedom index (GOVFREE) is also included in our models. This index reflects the level of government expenditures (including consumption and transfers) as a ratio of GDP. The inclusion of this variable follows the analysis of Aidis et al. (2012) who find that the entrepreneurship rates are inversely related to the size of the government. Additionally, to control for government imposed frictions in the financial industry we use the financial freedom (FINFREE) component of the "index of economic freedom". The inclusion of this index in the analysis is important in order to ensure that the foreign presence variable does not merely reflect privatisation.

Furthermore, we employ the overall regulatory quality index (REGWB) from the World Bank Governance Indicators to account for the ability of governments to design and implement regulation beneficial to private sector development. This regulatory quality index is a composite index that takes into account regulatory quality in all areas of the economy. It ranges from -2.5 to 2.5 , with higher values denoting a better regulatory framework. The use of this index eases omitted variable concerns with regards to types of regulation other than ones that we specifically include in the models. Moreover, in order to ensure that the foreign bank presence variable in our analysis does not capture an effect related to general inward FDI (Kouretas and Tsoumas 2016) we include in our models as control variable the ratio of FDI inflows to GDP (INFDI). We source this variable from the World Development Indicators (WDI) database of the World Bank. Finally, in order to control for the level of competition in the banking industry in each economy, we use the concentration ratio as measured by the assets of the three largest commercial banks as a share of total commercial banking assets (C3). The inclusion of this control variable is important because the competitive conditions in the banking industry could affect new firm entry (Cetorelli and Strahan 2006). We source the C3 variable from the Global Financial Development Database of the World Bank. ${ }^{5}$ In Tables 1 and 2 we provide the detailed definition of the variables that we include in this study and some descriptive statistics.

\footnotetext{
${ }_{5}^{5}$ In alternative estimations we use as a measure of competition in the banking industry the Lerner index at the country level. The Lerner index is also available in the Global Financial Development Database of the World Bank but is available for fewer years than the $\mathrm{C} 3$ ratio. Thus, we report the estimations that employ the $\mathrm{C} 3$ ratio as a measure of bank competition. The results are qualitatively similar when we employ the Lerner index as a measure of competition.
} 


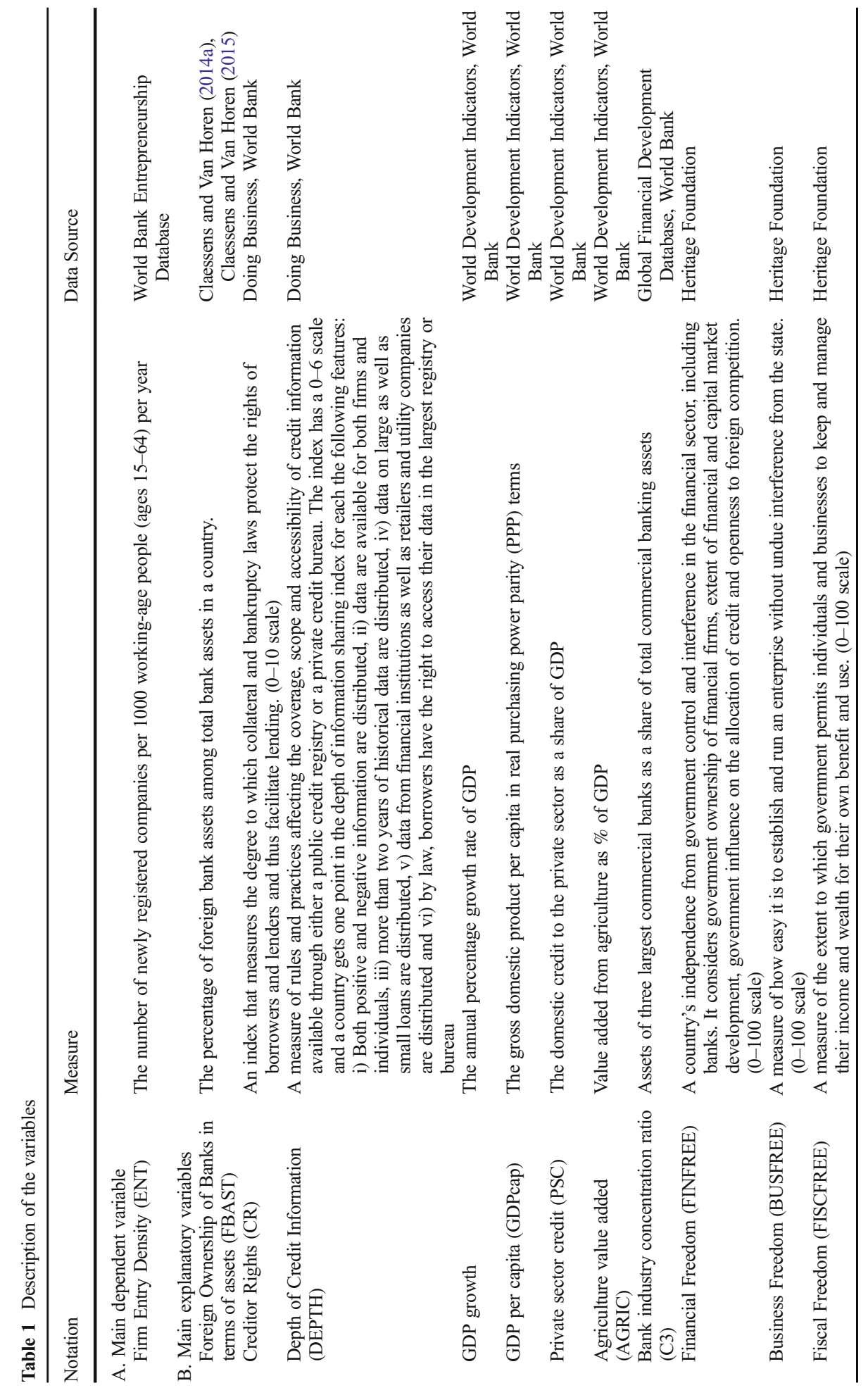




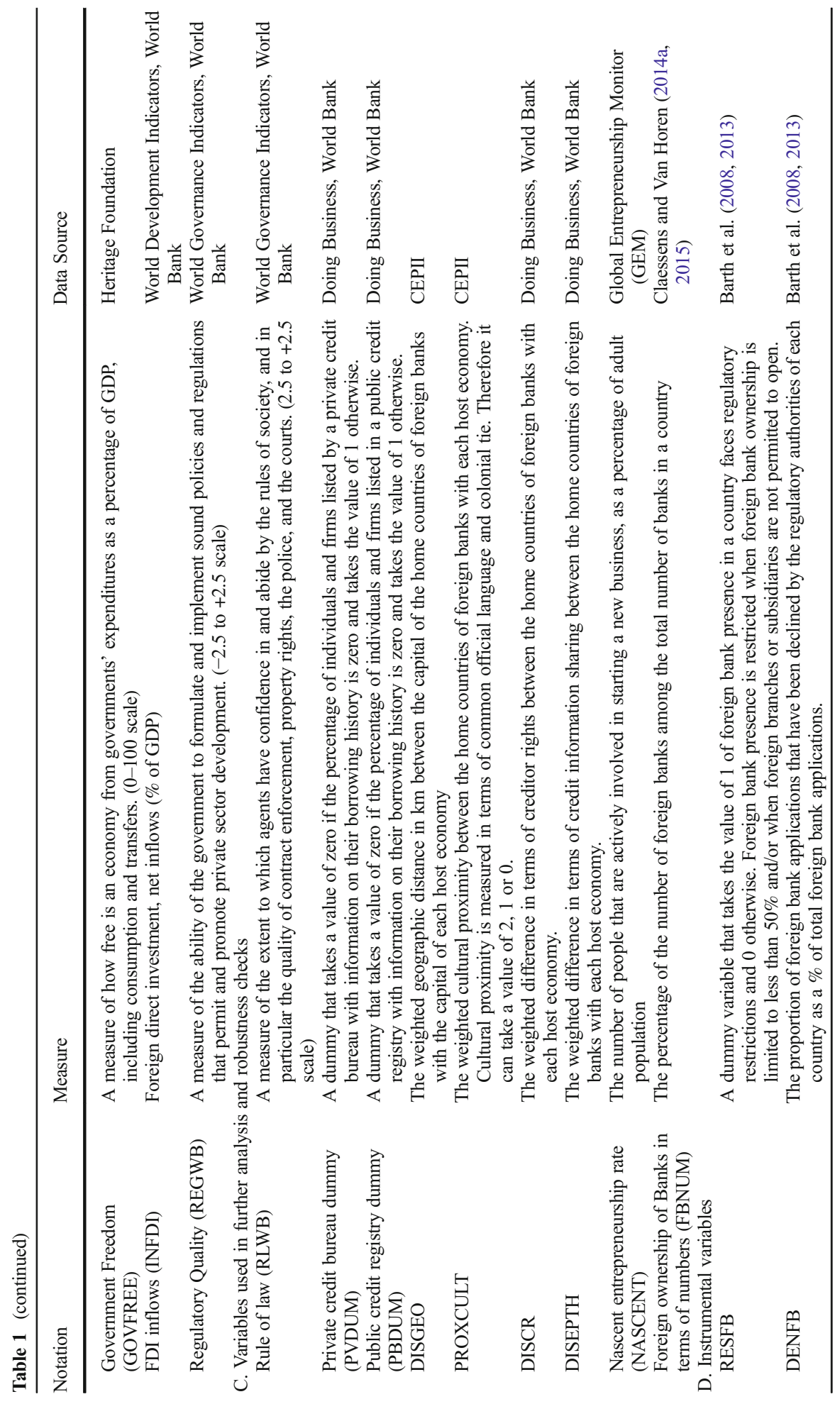


Table 2 Descriptive statistics

\begin{tabular}{|c|c|c|c|c|c|}
\hline Variable & Obs & Mean & Std. Dev. & Min & Max \\
\hline Firm Entry Density (ENT) & 691 & 3.337 & 4.139 & 0 & 32.6 \\
\hline Foreign Ownership of Banks in terms of assets (FBAST) & 673 & 44.521 & 33.815 & 1 & 100 \\
\hline Foreign Ownership of Banks in terms of numbers (FBNUM) & 682 & 44.698 & 26.722 & 1 & 100 \\
\hline Creditor Rights (CR) & 691 & 5.999 & 2.414 & 0 & 10 \\
\hline Depth of Credit Information (DEPTH) & 691 & 3.318 & 2.321 & 0 & 6 \\
\hline GDP per capita (GDPcap) & 682 & 21,586 & 18,242 & 575 & 96,711 \\
\hline GDP growth & 691 & 3.479 & 4.139 & -14.814 & 17.291 \\
\hline Private sector credit (PSC) & 632 & 68.559 & 52.567 & 0.010 & 227.527 \\
\hline Agriculture value added as $\%$ of GDP (AGRIC) & 679 & 9.439 & 9.549 & 0.034 & 43.206 \\
\hline Bank industry concentration ratio $(\mathrm{C} 3)$ & 661 & 71.495 & 19.830 & 21.695 & 100 \\
\hline Financial Freedom (FINFREE) & 676 & 59.201 & 18.150 & 10 & 90 \\
\hline Business Freedom (BUSFREE) & 676 & 72.532 & 14.303 & 28.8 & 100 \\
\hline Fiscal Freedom (FISCFREE) & 676 & 73.899 & 13.744 & 32.7 & 99.9 \\
\hline Government Freedom (GOVFREE) & 674 & 61.089 & 22.869 & 2.2 & 96.1 \\
\hline Regulatory Quality (REGWB) & 682 & 0.491 & 0.857 & -1.638 & 1.971 \\
\hline FDI inflows (INFDI) & 682 & 5.863 & 9.988 & -58.978 & 142.257 \\
\hline Rule of law (RLWB) & 682 & 0.337 & 0.974 & -1.653 & 2.000 \\
\hline Public credit registry dummy (PBDUM) & 691 & 0.499 & 0.500 & 0 & 1 \\
\hline Private credit bureau dummy (PVDUM) & 691 & 0.654 & 0.476 & 0 & 1 \\
\hline Nascent entrepreneurship rate (NASCENT) & 392 & 5.838 & 4.647 & 0.89 & 31.3 \\
\hline Distance in terms of creditor rights (DISCR) & 663 & 1.145 & 3.095 & -10 & 8.3 \\
\hline Distance in terms of information sharing (DISEPTH) & 663 & -0.409 & 2.421 & -6 & 6 \\
\hline Proximity in terms of culture (PROXCULT) & 669 & 0.404 & 0.529 & 0 & 2 \\
\hline Geographic distance in $\ln$ (DISGEO) & 670 & 8.193 & 1.007 & 5.683 & 9.721 \\
\hline Foreign bank regulatory restrictions (RESFB) & 619 & 0.168 & 0.374 & 0 & 1 \\
\hline Foreign bank denied applications ratio (DENFB) & 623 & 0.050 & 0.155 & 0 & 1 \\
\hline
\end{tabular}

\subsection{Methods}

We provide results from both fixed effects and dynamic panel specifications. The fixed effect estimator takes the following form:

$$
(\ln E N T)_{i, t}=\left[a_{0}+\beta_{1} \sum_{j=1}^{n}(\text { Control })_{i, t}+\beta_{2}(\operatorname{lnFBAST})_{i, t}+\beta_{3}\left(C R_{i, t}\right)+\beta_{4}\left(\text { DEPTH } H_{i, t}\right)+v_{i}+m_{t}+u_{i, t}\right],
$$

where $(\ln E N T)_{i, t}$ is the natural logarithm of the new firm entry measure observed in country $i$ at time $\mathrm{t}, \ln F B A S T$ is the natural logarithm of the measure of foreign bank presence, $C R$ is the creditor rights index, $D E P T H$ is the information sharing index, Control is a vector of control variables, $v$ are country fixed effects, $m$ are time effects and $u$ is the stochastic term. By employing country fixed effects we capture unobserved country heterogeneity. That is we account for all the time-invariant characteristics of the countries we include in our sample and could affect new firm entry rates (e.g. geographic position, culture etc.). By employing time effects we also account for shocks common to all countries, which is important in this study which encompass the years of the recent financial crisis. We perform the fixed effects estimations with robust standard errors.

There are two important concerns with the above identification strategy. The first is the potential persistence of entrepreneurship rates (Dutta and Sobel 2016). The second is the potential endogeneity between the new firm entry rate (lnENT) and the foreign bank presence (lnFBAST) variable. It could be the case that foreign banks may find attractive to enter economies with high entrepreneurship rate (Havrylchyk 2012). For these two reasons, we 
opt to estimate also dynamic models using the two-step system generalized method of moments estimator (GMM) as advanced by Arellano and Bover (1995) and Blundell and Bond (1998), using corrected robust standard errors (Windmeijer 2005).

The two-step system GMM models include among the rest of the explanatory variables, one lag of the new firm entry rate variable (lnENT), and therefore, eq. (1) takes the following form:

$$
(\ln E N T)_{i, t}=\left[a_{0}+\beta_{1}(\ln E N T)_{i, t-1}+\beta_{2} \sum_{j=1}^{n}(\text { Control })_{i, t}+\beta_{3}(\operatorname{lnFBAST})_{i, t}+\beta_{4}\left(C R_{i, t}\right)+\beta_{5}\left(D_{E P T H}{ }_{i, t}\right)+v_{i}+m_{t}+u_{i, t}\right]
$$

The inclusion of the lagged dependent variable as a further explanatory variable in the model (2) accounts for the potential persistence of the new firm entry rate $(\ln E N T)$. Another virtue of the two-step system GMM estimator is that we can treat some of the explanatory variables as endogenous with the use of appropriate instruments. In our estimations we treat as endogenous the lagged dependent variable $\left((\ln E N T)_{i, t-1}\right)$ as it is the standard in the literature, the foreign bank presence variable (lnFBAST) and the business freedom (BUSFREE) variable. $^{6}$ This suggests that we use the second lag of the dependent variable, of the foreign bank presence variable and of the business freedom variable as instruments (Blundell and Bond 1998; Bond 2002). The results of the two-step system GMM estimator are also verified by Hansen's $J$ test for instrument validity and the second-order autocorrelation of the error terms test, AR2, as introduced by Arellano and Bond (1991).

\section{Empirical findings and discussion}

\subsection{Main analysis}

Table 3 shows the estimations of the determinants of new firm entry for the 2005-2013 period. The first model of Table 3 shows the baseline fixed effects results, while in the rest of the fixed effects models (2 to 4 ) we interact the foreign bank presence variable (lnFBAST) with the creditor rights $(\mathrm{CR})$ and the information sharing (DEPTH) variables.

The results of the baseline model 1 in Table 3 show that the foreign bank presence (lnFBAST) exerts a significant at the $5 \%$ level positive effect on new firm entry. This result provides evidence in support of hypothesis $H 1 . B$ that foreign bank presence increases new firm entry.

This result conforms with the literature that posits that foreign banks, by employing advanced lending technologies, could overcome the informational disadvantages that they face in the credit markets of the host economies and thus be able to facilitate lending to opaque borrowers (Clarke et al. 2005; De Haas and Naaborg 2006; Bruno and Hauswald 2014) such as aspiring entrepreneurs. Through another channel, foreign bank presence could have a positive effect on new firm entry indirectly by motivating domestic banks to increase their credit supply

\footnotetext{
${ }^{6}$ Initially, we attempted to employ as endogenous variables just the lagged dependent variable $\left(\operatorname{lnENT} \mathrm{t}_{\mathrm{t} 1}\right)$ and the foreign bank presence variable (lnFBAST). In this case we obtain significant $p$-values for the Hansen $J$ test. We find that by treating the lagged dependent variable $\left(\operatorname{lnENT} \mathrm{t}_{\mathrm{t}-1}\right)$, the foreign bank presence variable $(\ln \mathrm{hBAST})$ and the business freedom (BUSFREE) variable as endogenous we obtain insignificant $p$-values for the Hansen $J$ test. This suggests that the instruments are acceptable and the business freedom (BUSFREE) variable is better modelled as endogenous in the dynamic panel models. This also makes sense from a theoretical standpoint. The business freedom (BUSFREE) is a measure of regulation of firm entry and therefore it is rational to consider it as endogenous to the entrepreneurship rate.
} 


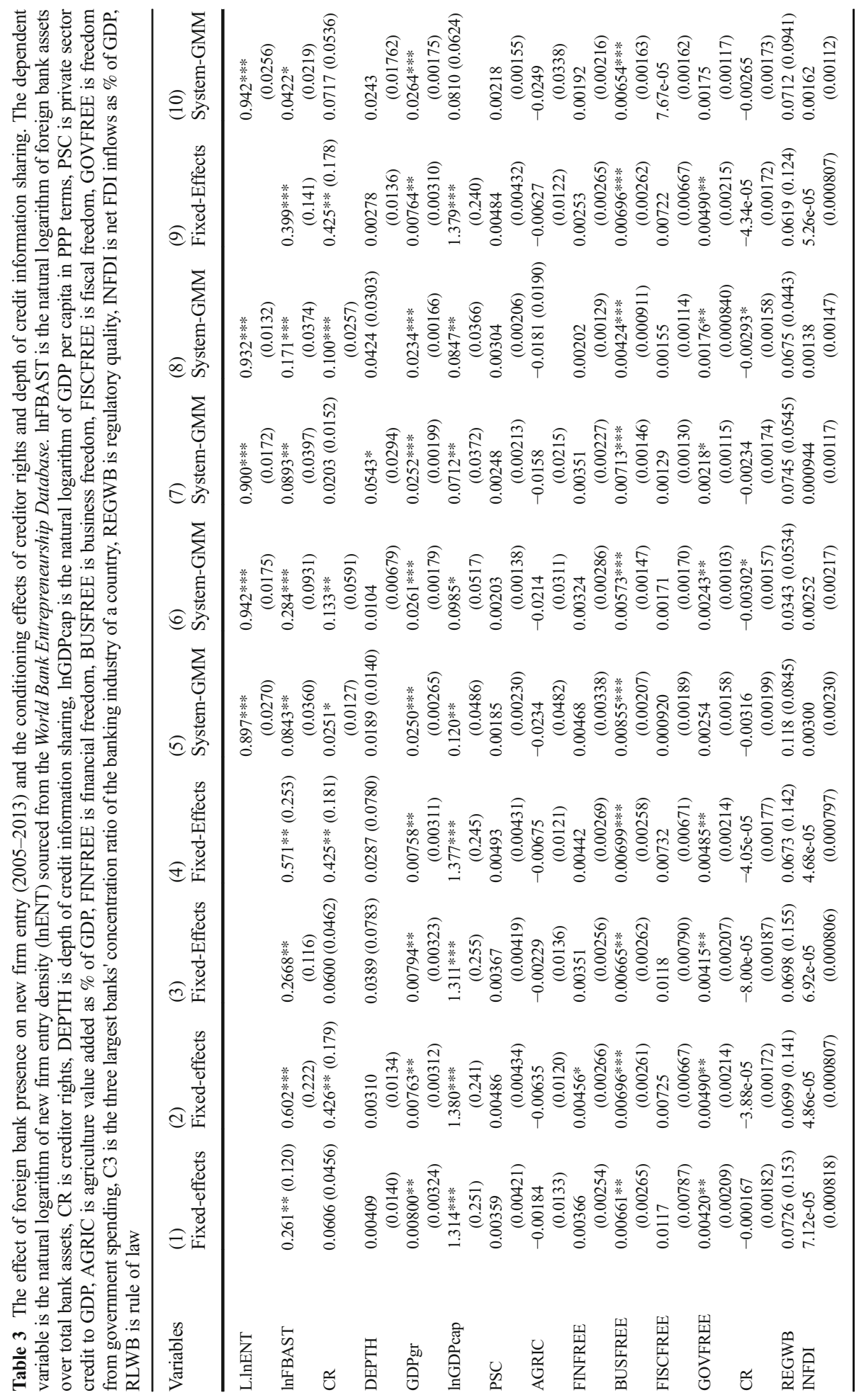




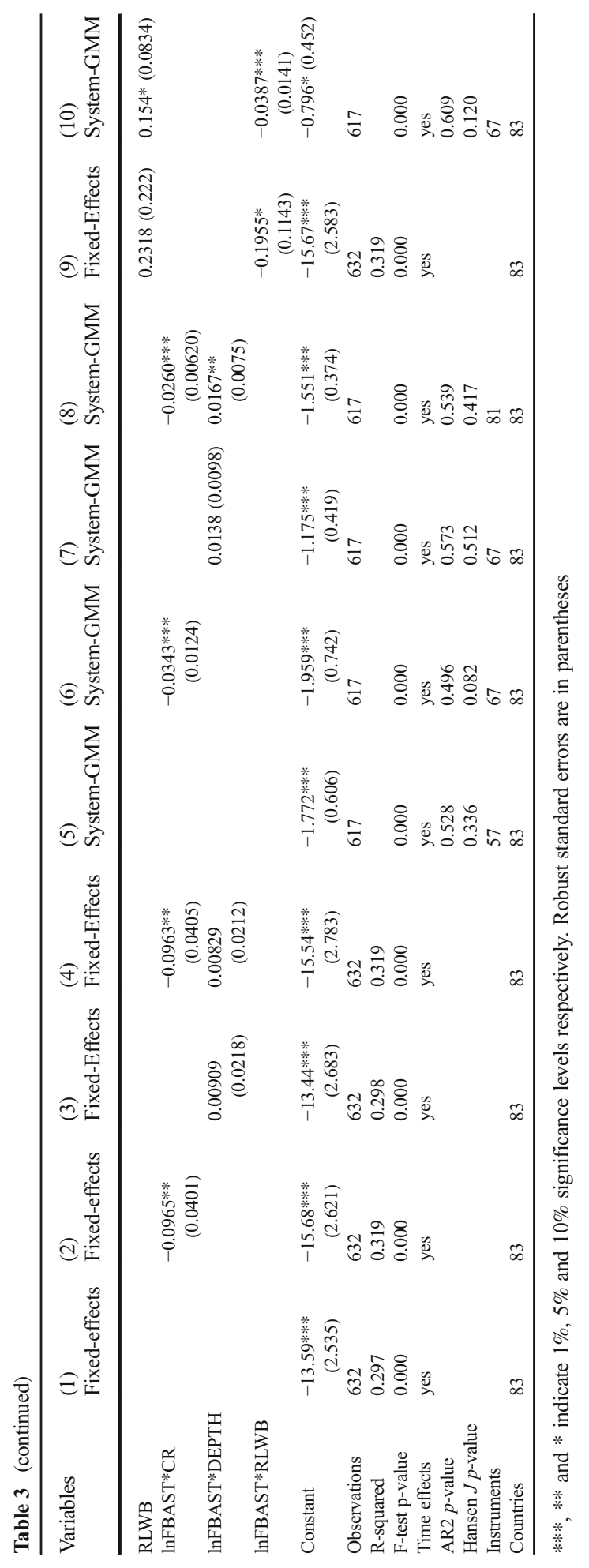


to less transparent clients (Clarke et al. 2001). There is empirical evidence showing that foreign banks tend to focus mostly on large and more transparent borrowers (Detragiache et al. 2008; Brown et al. 2011; Pennathur and Vishwasrao 2014). However, a potential"cherry-picking" behaviour of foreign banks does need to necessarily lead to a decline in credit towards opaque borrowers, as in Detragiache et al. (2008), but could rather indirectly improve their access to credit for the latter as the findings of Gianetti and Ongena (2012) demonstrate.

The models that include the interaction terms between foreign bank presence (lnFBAST) and the creditor rights (CR) and information sharing (DEPTH) variables reveal some interesting findings. In model 2 of Table 4 the interaction between foreign bank presence (lnFBAST) and creditor rights (CR) has a negative and significant at the $5 \%$ level effect on new firm entry while the individual effect of foreign bank presence (lnFBAST) on new firm entry is positive and significant at the $1 \%$ level. In support of hypothesis $H 2 . B$, the positive effect of foreign bank presence on new firm entry subdues at higher levels of creditor rights. This implies that foreign bank presence is particularly useful for entrepreneurship in countries with poor legal infrastructure in terms of creditor rights. This result conforms to the findings of Bruno and Hauswald (2014) that foreign banks could substitute for insufficient legal infrastructure in host economies. A reason for this could be the development by foreign banks of advanced lending technologies to overcome legal uncertainty in host economies such as credit scoring technologies or leasing (Berger and Udell 2006; De la Torre et al. 2010; Beck et al. 2016) and therefore be able to lend to the opaque segments of the credit market such as the market for entrepreneurial credit. Another potential channel through which the positive effect of foreign bank presence on new firm entry could subdue at higher levels of creditor rights could be the shift of foreign bank lending towards mortgages that are the typical form of collateralised lending (De Haas et al. 2010). In model 3 of Table 3 we interact the foreign bank presence variable (lnFBAST) with the information sharing variable (DEPTH) and find that this interaction term has a positive but not statistically significant coefficient while the individual of the lnFBAST is positive and significant at the 5\% level. This provides some tentative empirical evidence in support of hypothesis $H .3$ that information sharing could strengthen the positive effect of foreign bank presence on new firm entry. In model 4 of Table 3 we include the interaction term between foreign bank presence and creditor rights and the interaction term between foreign bank presence and information sharing in the same model and the results we obtain are similar.

In models 5 to 8 of Table 3 we provide the results of the dynamic panel estimations. The results of the baseline dynamic panel model 5 in Table 3 reveal that the lag of the dependent variable, the natural $\log$ of the new firm entry rate $(\operatorname{lnENT})$, has a positive and significant at the $1 \%$ level coefficient. Furthermore, its large magnitude (0.897) denotes a high persistency of the new firm entry rate. This finding justifies the use of dynamic panel analysis in this study. With regards to the effect of foreign bank presence (lnFBAST) on new firm entry we find that it is positive and statistically significant at the $5 \%$ level lending support to the empirical findings of the fixed effects models. In models 6 to 8 of Table 3 we include the interaction terms of foreign bank presence (lnFBAST) with creditor rights (CR) and information sharing (DEPTH). ${ }^{7}$ In model 6 of Table 3 we find that the interaction between foreign bank presence (lnFBAST) and creditor rights (CR) is negative and significant at the $1 \%$ level while the individual effect of foreign bank presence (lnFBAST) on new firm entry is positive and significant at the $1 \%$ level. This provides further

\footnotetext{
${ }^{7}$ Note that since in the dynamic panel analysis we treat foreign bank presence (lnFBAST) as endogenous, we also treat as endogenous the interaction terms of this variable with creditor rights $(\mathrm{CR})$ and information sharing (DEPTH) (Asiedu and Lien 2011).
} 


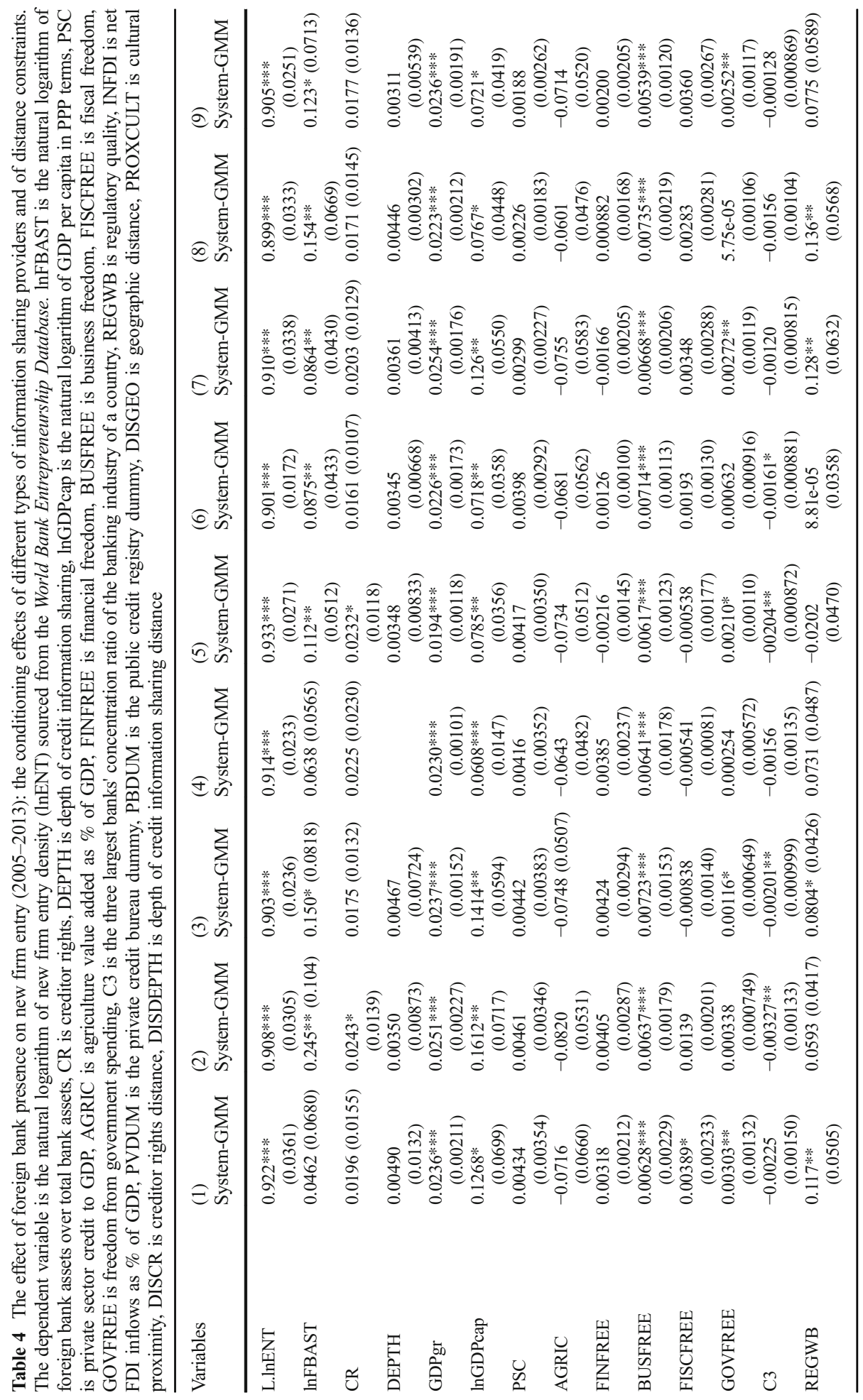




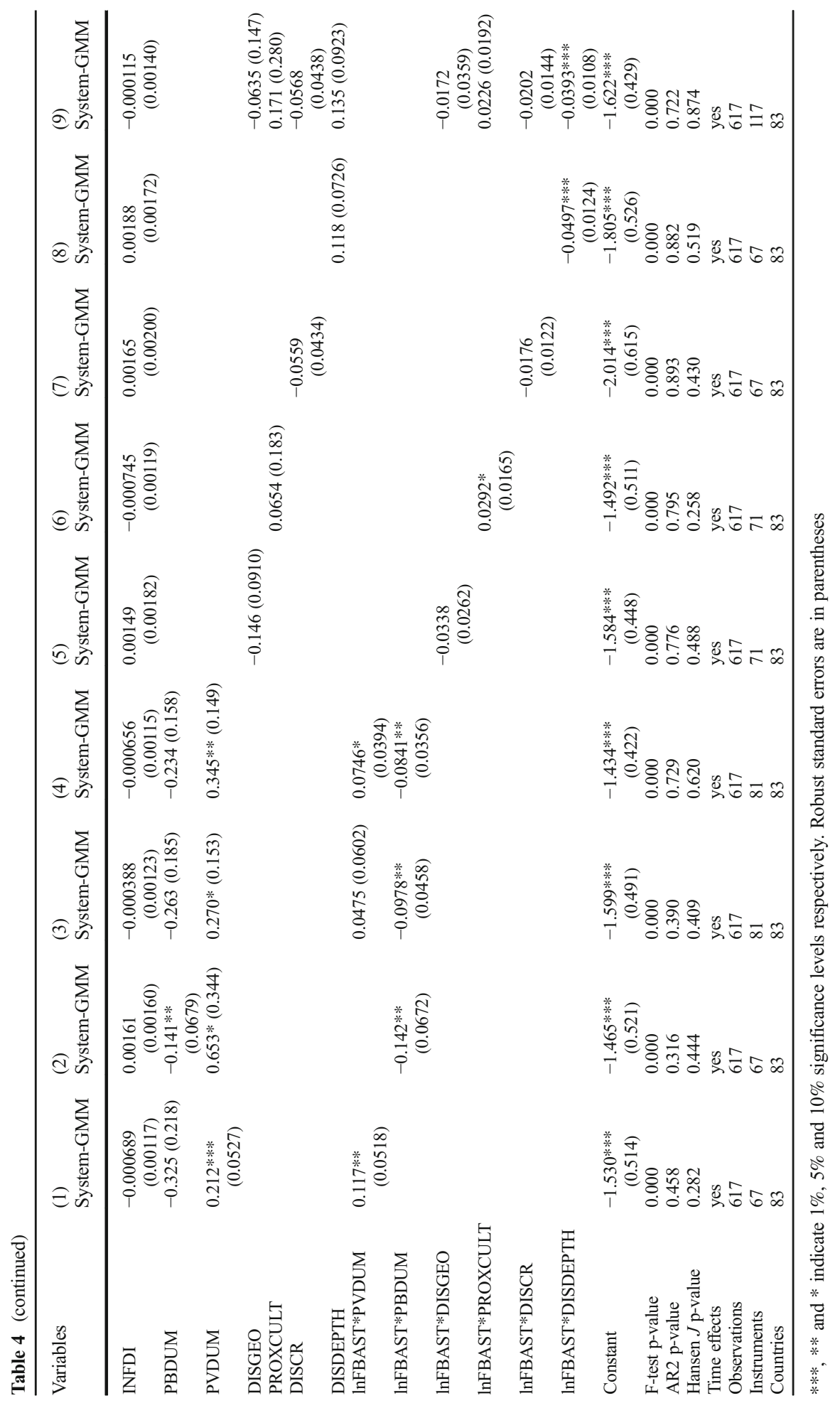


support to the results of the fixed effects models that foreign banks could particularly promote entrepreneurship in uncertain legal environments. In model 7 of Table 3 we find, similarly to the fixed effects estimations, that the interaction between foreign bank presence (lnFBAST) and information sharing (DEPTH) is positive but not statistically different from zero. However, in model 8 of Table 3, when we include all the interaction terms in the same dynamic panel specification, we find a positive and statistically significant at the $5 \%$ level coefficient for the lnFBAST*DEPTH interaction. This result provides some evidence that the positive effect of foreign bank presence on new firm entry strengthens at higher levels of credit information sharing in accordance with hypothesis $H .3$. Foreign banks seem to benefit new firm entry disproportionally in host economies in which they face a lower level of information asymmetries as proxied by credit information sharing. Therefore, credit information sharing could alleviate the negative effects of a potential foreign bank "cherry-picking" behaviour on the credit provision to opaque credit market segments, such as the market for entrepreneurial credit, as the findings of Detragiache et al. (2008) would suggest. One of the reasons could be that information sharing could empower the lending technologies that foreign banks employ to provide credit to opaque domestic borrowers. For example, personal information on the past borrowing behaviour of an aspiring entrepreneur, sourced from credit bureaus or registries, could be employed as input in the credit scoring models that foreign banks could use in the market for entrepreneurial credit (Berger and Udell 2002; Black and Strahan 2002; Berger and Udell 2006). Furthermore, higher levels of information sharing in the host economy could induce foreign banks to extend credit to more opaque borrowers, such as potential new firm entrants, because of the disciplinary effect information sharing could have on the latter (Klein 1992).

In order to enhance our analysis with regards to the conditioning effects stemming from the interaction between foreign bank presence and creditor rights we provide estimations using an alternative measure of creditor rights. More specifically, instead of interacting foreign bank presence with the creditor rights (CR) index, we interact it with a measure of rule of law (RLWB) in the host economies. We source the rule of law (RLWB) variable from the World Governance Indicators of the World Bank, and it measures the degree of the contract enforcement, property rights and court efficiency. These results are available in models 9 and 10 of Table 3. We provide estimations from both fixed-effects (model 9 of Table 3 ) and dynamic panel specifications (model 10 of Table 3). The results we obtain from these models are consistent with the results we obtained from the rest of the models in Table 3 and provide further evidence in support of the hypothesis H2.B. More specifically we find that in the models 9 and 10 of Table 3 the interaction term between foreign bank presence (lnFBAST) and the rule of law (RLWB) is negative and significant. This result lends further support to the previous findings that the beneficial effect of foreign bank presence on new firm entry subdues when contract enforcement regulation improves in line with Bruno and Hauswald (2014).

With regards to the individual effects of creditor rights and information sharing we find, in most models of Table 3, that they have a positive association with new firm entry. This positive association of creditor rights (CR) and information sharing (DEPTH) with new firm entry is statistically significant in most models for the former variable. This finding underscores the importance of collateral in obtaining bank credit for entrepreneurial activities in line with the findings of Robb and Robinson (2013). Furthermore, this result provides further evidence that personal collateral from the aspiring entrepreneurs must often be posted to secure financing for new firm entry (Avery et al. 1998; Moon 2009).

Finally, in terms of the control variables we find in most specifications of Table 3 that new firm entry has a positive association with GDP growth and economic development 
(lnGDPcap) in line with the findings of Bruno et al. (2013) and Klapper et al. (2015). Additionally, business freedom (BUSFREE) has a positive and significant association with new firm entry in most specifications. This result highlights the importance of less stringent regulation of entry in facilitating entrepreneurship in line with the findings of Klapper et al. (2006). We also find that concentration ratio in the banking industry (C3) has a negative and, in some specifications, statistically significant association with new firm entry. This result is in line with the study of Cetorelli and Strahan (2006) who find that potential new firm entrants face greater difficulty in obtaining credit in less competitive bank markets. Furthermore, we find that limited government size (GOVFREE) has a positive and significant association with new firm entry in line with Aidis et al. (2012).

\subsection{Further analysis}

\subsubsection{Conditional effects of different types of information sharing providers (Private Credit Bureaus Vs Public Credit Registries)}

So far the analysis provides evidence that the positive effect of foreign bank presence on new firm entry strengthens at higher levels of depth of credit information sharing. In this section we go one step further and examine for conditioning effects with regards to the distinction of information sharing providers between public credit registries and private credit bureaus. This distinction is important as these two types of credit information providers can differ significantly in the availability of credit history and the associated information they might contain. OECD (2010) reports that private credit bureaus have some distinct advantages over public credit registries. Public credit registries collect information mainly on large borrowers, they are subject to stricter privacy laws and they usually do not provide additional services such as borrower credit ratings. Additionally, recent empirical evidence casts doubt on the reliability of the credit information available in the public credit registries (Giannetti et al. 2016). Furthermore, some microeconometric studies find that it is the introduction of private credit bureaus, and not the introduction of public credit registries, that benefit the access to bank credit for opaque borrowers (Love and Mylenko 2003; Martínez Pería and Singh 2014; Grajzl and Laptieva 2016). It could be the case therefore that private credit bureaus are more able than public registries to decrease the information asymmetries that foreign banks face in host economies especially as far as concerns the opaque credit market segments such as the one for entrepreneurial credit. In line with this argument, empirical evidence from Tsai et al. (2011) suggests that the presence of private credit bureaus is an important factor that foreign banks take into account when they decide where to locate internationally.

Based on the above discussion we formulate the following hypothesis $(\mathrm{H} 4)$ :

\section{H4: The presence of a private credit bureau would be more beneficial than the presence of a public credit registry in terms of the effect of foreign bank presence on new firm entry}

To proceed to this type of analysis we follow an approach similar to Tsai et al. (2011) and construct two dummy variables that would indicate the presence of a) a public credit registry (PBDUM) and b) a private credit bureau (PVDUM). Therefore, we employ the public credit registry and private credit bureau coverage indices of the Doing Business dataset of the World Bank. More specifically, if a country at a specific year has a $0 \%$ population and firm coverage 
through a public registry we assume the absence of a public credit registry. In a similar manner, we construct the dummy variable for the presence of a private credit bureau. The models that include the interaction terms between foreign bank presence (lnFBAST) and the public credit registry (PBDUM) and private credit bureau (PVDUM) dummies are available in Table 4 (models 1-4). We provide results from the dynamic panel specifications as we obtain similar results with the fixed effects estimator.

The empirical findings provide evidence in support of hypothesis $H 4$. In models 1 and 3 of Table 4 we find that the interaction term between the presence of a private credit bureau and foreign bank presence (lnFBAST*PVDUM) enters with a positive coefficient, which is statistically significant at the 5\% level only in the former model. In model 4 we drop from the specification the depth of information sharing variable (DEPTH). This variable (DEPTH) reflects the richness of information sharing either from a private credit bureau or a public credit registry. Since private credit bureaus usually provide much richer information on borrowers than public credit registries, the inclusion of the DEPTH variable in the models could absorb explanatory power from the private credit bureau dummy. ${ }^{8}$ Indeed, in model 4 we find that the interaction between foreign bank presence and the private credit bureau dummy is positive and significant at the $10 \%$ level. These results provide evidence that the positive effect of foreign bank presence on new firm entry strengthens in the presence of a private credit bureau. The existence of a private credit bureau, which contains also information on small borrowers and provides credit rating information (OECD 2010; World Bank 2014), could be of importance for foreign banks in extending credit to the opaque credit market segments such as the one of entrepreneurial credit. This could be because "hard" information availability on small borrowers could decrease the information asymmetry between them and foreign banks by empowering the use of transaction-based lending technologies, such as credit scoring models, that the latter tend to rely on. It is also worth noting that in most specifications the individual effect of the private credit bureau dummy (PVDUM) has a positive and statistically significant association with new firm entry. This denotes that private credit bureaus could enhance credit availability to entrepreneurial activities also through the domestic banking sector. This is consistent with the recent empirical evidence from Martínez Pería and Singh (2014).

With regards to the public credit registry dummy (PBDUM) we find in models 2, 3 and 4 of Table 4 that its interaction with foreign bank presence (lnFBAST*PBDUM) is negative and significant at the 5\% level. Thus, the positive effect of foreign bank presence on new firm entry subdues in the presence of a public credit registry. Public credit registries report information mostly on large firms with high credit exposure and large firms are a segment of the market favored by foreign banks (Pennathur and Vishwasrao 2014). Therefore information on these firms might induce foreign banks to gear lending towards this type of firms and less on the more opaque segments of the credit market such as the market for entrepreneurial credit. This would be consistent with the findings of Detragiache et al. (2008).

\subsubsection{Conditional Effects of Distance Constraints between Home and Host Economies}

We further examine if distance constraints between the home and the host countries condition the effect of foreign bank presence on new firm entry. Distance constraints between a bank's

\footnotetext{
${ }^{8}$ The correlation (see Table 8 in the appendix) between the depth of information sharing (DEPTH) and the presence of private credit bureau dummy (PVDUM) is around 0.7 , while it is only 0.066 with the public credit registry dummy (PBDUM). This provides evidence that private credit bureaus are the main source of the depth of information sharing in a given country.
} 
headquarter and loan officers renders harder the reliance on "soft" information on local borrowers and therefore exacerbates information asymmetries (Stein 2002; Liberti and Mian 2009). Therefore, geographic and cultural distance constraints could induce foreign banks to focus mostly on large and transparent borrowers in the host economy (Beck et al. 2016) and shy away from the least transparent credit markets segments such as the one for entrepreneurial credit. In line with this, Mian (2006) provides empirical evidence that geographic and cultural distance between foreign banks' headquarters and branches in the host economy induces them to avoid lending to informationally opaque borrowers. In another study Berger et al. (2001) find that distant foreign banks face more hurdles to lend to less transparent borrowers in Argentina. However, it is not only geographic and cultural distance that could matter but also institutional distance. Ongena et al. (2013) show that home country institutional characteristics define the business model that foreign banks tend to export in the host economies and this affects their lending activities in the latter. It could be easier for a foreign bank to apply its business model and its advanced lending technologies in a familiar institutional environment in the host economy (Claessens and Van Horen 2014b). Based on the above discussion we formulate the following hypothesis (H5):

\section{H5: Geographic, cultural and institutional distance constraints (proximity) could negatively (positively) condition the effect of foreign bank presence on new firm entry}

To test this hypothesis we interact variables that reflect geographic distance, cultural proximity and institutional distance in terms of creditor rights and credit information sharing with the foreign bank presence variable. To construct the distance and proximity variables we follow an approach similar to Delis et al. (2016). To this end, we calculate the weighted distance (proximity) between the multiple home countries related with the foreign banks present in each host economy with the host economy. More specifically, we first calculate the distance (proximity) between each foreign country and a host economy for a given characteristic and then estimate a weighted average. We use as weights the ratio of each foreign country's bank assets over the total foreign bank assets in each host economy. Therefore, the weighted distance variables are equal to the sum of the multiplication outcomes of these weights with the distance (proximity) of each considered variable between multiple foreign home countries and each host economy. We construct three distance variables that reflect geographic distance (DISGEO) and institutional distance in terms of creditor rights (DISCR) and depth of credit information sharing (DISDEPTH). We also construct a cultural proximity variable, (PROXCULT), which ranges between 0 and 2. Cultural proximity could take maximum value of 2 when there is a colonial link (value of 1) and the same official language (value of 1), while 0 otherwise. ${ }^{9}$

The results of the specifications that include the interaction terms of these distance (proximity) variables with foreign bank presence are available in Table 4 (see models 5 to 9). We provide estimations from the dynamic panel models as we obtain similar results with the fixed effects estimator. The findings lend some support to hypothesis H5. The interaction term between cultural proximity (PROXCULT) and foreign bank presence (lnFBAST) enters model 6 of Table 4 with a positive and significant at the $10 \%$ level coefficient. Thus, the positive effect of

\footnotetext{
${ }^{9}$ We source the data to construct the cultural proximity and geographic distance variables from CEPII. www. cepii.fr. Note that the cultural proximity and geographic distance variables we construct are time variant. The geographic distance and cultural proximity between two given countries is time invariant but the weights that we multiply these characteristics with (i.e. the share of each home country's foreign bank assets over the total foreign bank assets in a given host economy) to construct the distance and proximity variables in this study are time variant.
} 
foreign bank presence on new firm entry strengthens at higher levels of cultural proximity between the home countries of foreign banks and the host economy. In model 8 of Table 4 we also find that the interaction term between distance in terms of credit information sharing (DISDEPTH) and foreign bank presence (lnFBAST) is negative and significant at the $1 \%$ level. ${ }^{10}$ Thus the positive effect of foreign bank presence on new firm entry weakens at higher levels of institutional distance in terms of information sharing between the home countries of foreign banks and a given host economy. This result underscores the importance of credit information sharing in reducing the information asymmetries that foreign banks face in a host economy in order to be able to lend to opaque borrowers such as aspiring entrepreneurs. Foreign banks that originate from countries with a high level of depth of credit information sharing could have developed lending technologies, such as credit scoring, in order to extend credit to opaque borrowers that could be highly dependent on inputs from credit bureaus or registries. Therefore their capacity to apply such lending technologies in a host economy to lend to opaque credit market segments, such as the one for entrepreneurial credit, would depend on credit information sharing availability. It is also worth noting that in model 9 of Table 4 only the interaction term between distance in terms of credit information sharing and foreign bank presence (DISDEPTH* $\operatorname{lnFBAST}$ ) retains its statistical significance. ${ }^{11}$ The latter finding highlights the importance of institutional in addition to geographic or cultural distance constraints (Mian 2006) in terms of the effect that foreign banks could have on the access to credit for opaque borrowers in the host economies.

\subsection{Robustness checks}

\subsubsection{IV estimations with alternative foreign bank presence variable and alternative dependent variable}

Another way, other than the use of a dynamic panel specification, to overcome the potential endogeneity between entrepreneurship and foreign bank presence is to employ an instrumental variable (IV) technique such as a two stage least square (2SLS) estimation. To this end, we need one or more instrumental variables that satisfy the exclusion restriction; that is, we need to identify one or more variables that affect foreign bank presence but do not affect entrepreneurship directly. It is evident in the literature (Detragiache et al. 2008; Giannetti and Ongena 2009; Gianetti and Ongena 2012; Delis et al. 2016) that foreign bank regulatory restrictions are a valid instrument for foreign bank presence. The empirical evidence suggests that the

\footnotetext{
${ }^{10}$ In unreported estimations we also run model 8 of Table 4 with the inclusion of a distance measure in terms of the level of economic development (lnGDPcap) and its interaction with the foreign bank presence variable. Our results are robust to this exercise. This is to ensure that the significant and negative effect of the interaction term between distance in terms of depth of credit information sharing (DISDEPTH) and foreign bank presence (lnFBAST) does not reflect differences between the home and host economies in terms of the level of economic development.

${ }^{11}$ Note that in model 9 of Table 4 we have instrument proliferation because we include all the interaction terms of the distance and proximity variables with the foreign bank presence variable in the same specification, and we have modelled these interactions as endogenous. Since the foreign bank presence variable is endogenous, its interaction term with other variables is also endogenous (Asiedu and Lien 2011), and this is the approach we have adopted in this paper. Roodman (2009) suggests that in dynamic panel models the ratio between instruments and cross-sections (i.e. countries in our case) should be smaller than unity. Model 9 of Table 4 is the only dynamic panel model in this study that the value of this ratio is higher than unity. Therefore, we have estimated again model 9 of Table 4 with the difference GMM estimator, which uses a lower number of instruments, rather than the system GMM estimator and we obtain qualitatively similar results. These estimations are available upon request.
} 
deregulation process in the banking sector exerts a positive effect on the expansion of foreign banks (Claessens and Van Horen 2014b). Furthermore, it is unlikely that regulatory restrictions for foreign banks would have a direct effect on entrepreneurship.

Thus, we employ two instrumental variables that reflect foreign bank regulatory restrictions in the host economy. The first one, a de jure measure of foreign bank regulatory restrictions, is a dummy variable (RESFB) that takes the value of 1 if foreign bank presence is restricted and 0 otherwise. To construct this variable we follow an approach similar to Claessens and Van Horen (2014b), whereby foreign bank presence is constrained in case foreign bank ownership is limited to less than $50 \%$ and/or when subsidiaries or branches are not permitted to open. The second instrumental variable, a de facto measure of foreign bank regulatory restrictions, is the proportion of the applications received from foreign bank entities that have been denied by the regulators in the host economy (DENFB). Data for both these instrumental variables are obtained from the 2006 and 2011 bank regulation surveys and their accompanied papers of Barth et al. $(2008,2013) .^{12}$

We provide estimations from 2SLS models with fixed effects and robust standard errors that employ the above instruments in Table $5 .{ }^{13}$ In these models we employ an alternative foreign bank presence variable; the natural logarithm of the percentage ratio of the number of foreign banks over the total number of banks in a host economy (lnFBNUM). This variable better reflects foreign bank entry in comparison with the asset-based foreign bank presence variable (lnFBAST) we used in the main analysis. Furthermore, in models 1 to 4 of Table 5 we use the same dependent variable (lnENT) that we have employed in our main analysis. However, in models 5 to 8 of Table 5 we employ an alternative dependent variable to proxy for entrepreneurship. More specifically, we use country data on nascent entrepreneurship that we source from the Global Entrepreneurship Monitor (GEM). In this database, nascent entrepreneurship at the country level is measured as the number of people that are actively involved in starting a new business, as a percentage of the adult population. This measure of entrepreneurship has been employed in several studies of the determinants of new firm entry (e.g. Wennekers et al. 2005; BaliamouneLutz and Garello 2014). ${ }^{14}$ We employ the natural logarithm of this measure (lnNascent).

The first stage results from the 2SLS IV models in Table 5 indicate that the two instrumental variables (RESFB and DENFD) have a negative and significant at the $1 \%$ level effect on the foreign bank presence variable (see lower part of Table 5) while they do not exert a significant direct effect on our entrepreneurship measures (see Table 9 in the appendix). Furthermore, in all models of Table 5 the validity of the instruments is demonstrated by the under-identification LM test (UIT), the weak identification Wald F-Test (WIT) ${ }^{15}$ and the overidentification test of Hansen (OIT).

The second stage results of the models in Table 5 provide empirical support to our previous findings. In most models of Table 5 the alternative foreign bank presence variable (lnFBNUM)

\footnotetext{
${ }^{12}$ We assign the regulatory data following the literature (Houston et al. 2010; Fratzscher et al. 2016). Specifically, we assign values from the 2006 survey to the period 2004-2007 and the data employed between 2008 and 2013 are sourced from the 2011 survey.

${ }^{13}$ Note that in the models of Table 5 that include interaction terms between the foreign bank presence variable (lnFBNUM) and other country characteristics, following Giannetti and Ongena (2009), we also instrument these interaction terms with the interactions between the instrumental variables RESFB and DENFB with the corresponding country characteristics. This procedure is important because the interaction between an endogenous variable and another variable is also endogenous (Asiedu and Lien 2011). However, not instrumenting for the interaction terms does not yield significant changes in our results.

${ }^{14}$ The GEM database has less coverage in terms of countries in comparison with the World Bank Entrepreneurship Database.

${ }^{15}$ We obtain critical values for the WIT from Stock and Yogo (2005).
} 


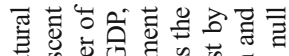

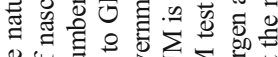

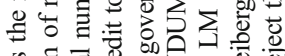

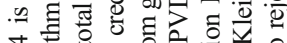

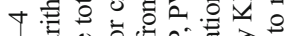

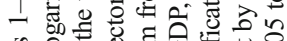
응

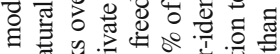

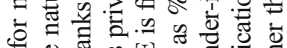

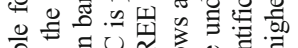
웡.s.

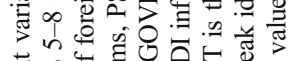

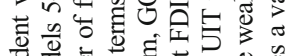
उั0

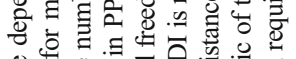

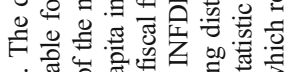

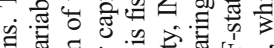

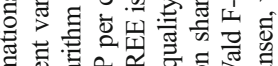

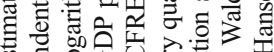

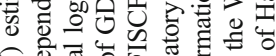

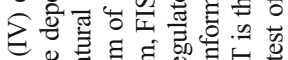

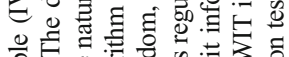

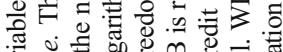
政 记

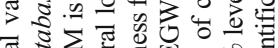

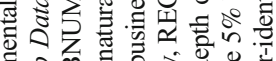
政

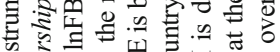
을 n

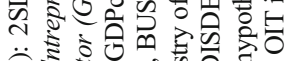

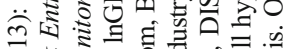
诺 它 o \& 等 흘

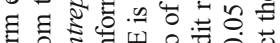

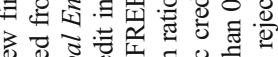

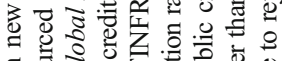
亏

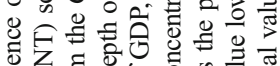

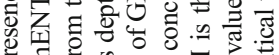
들

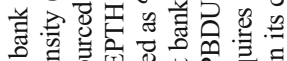

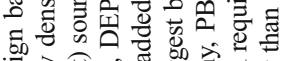

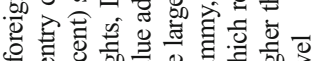
to

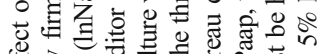

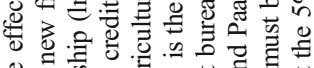

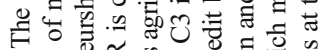

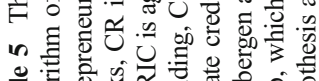

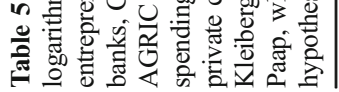

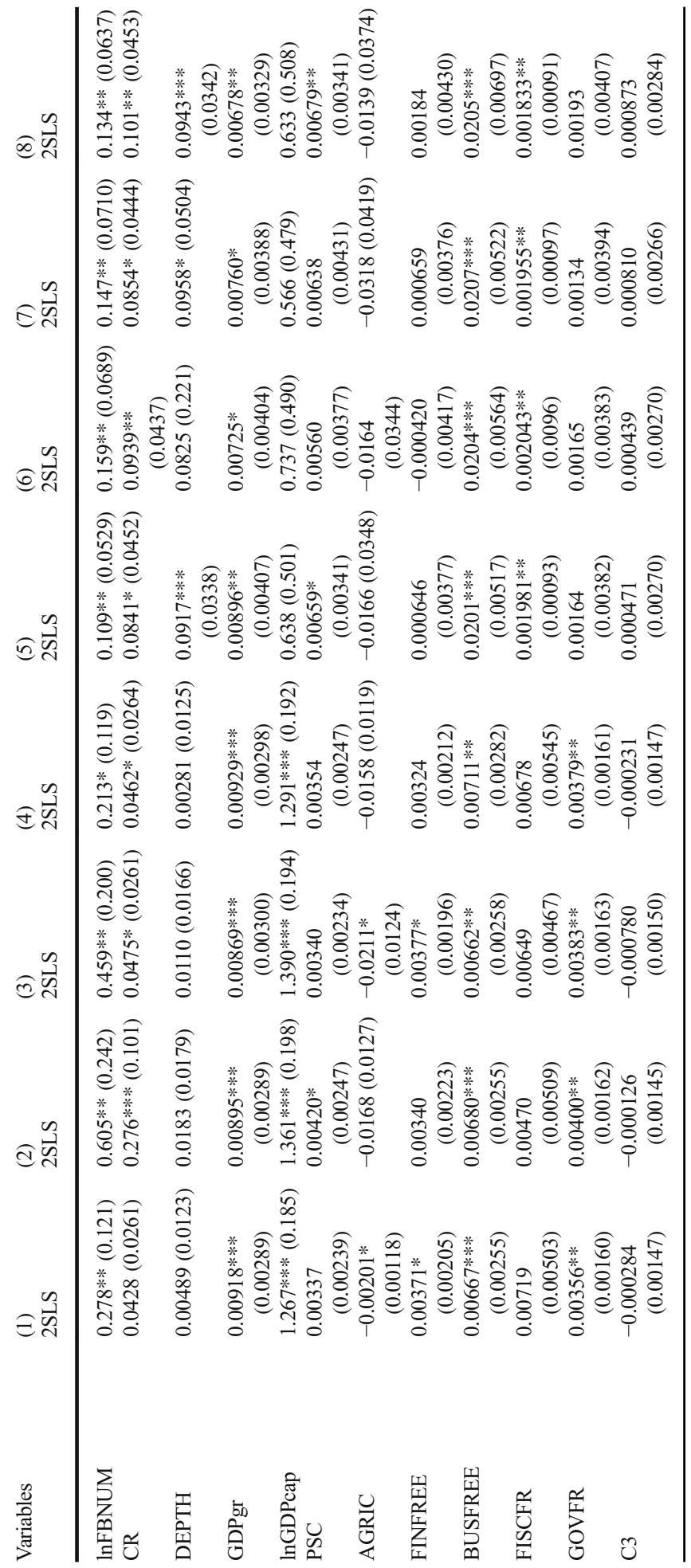




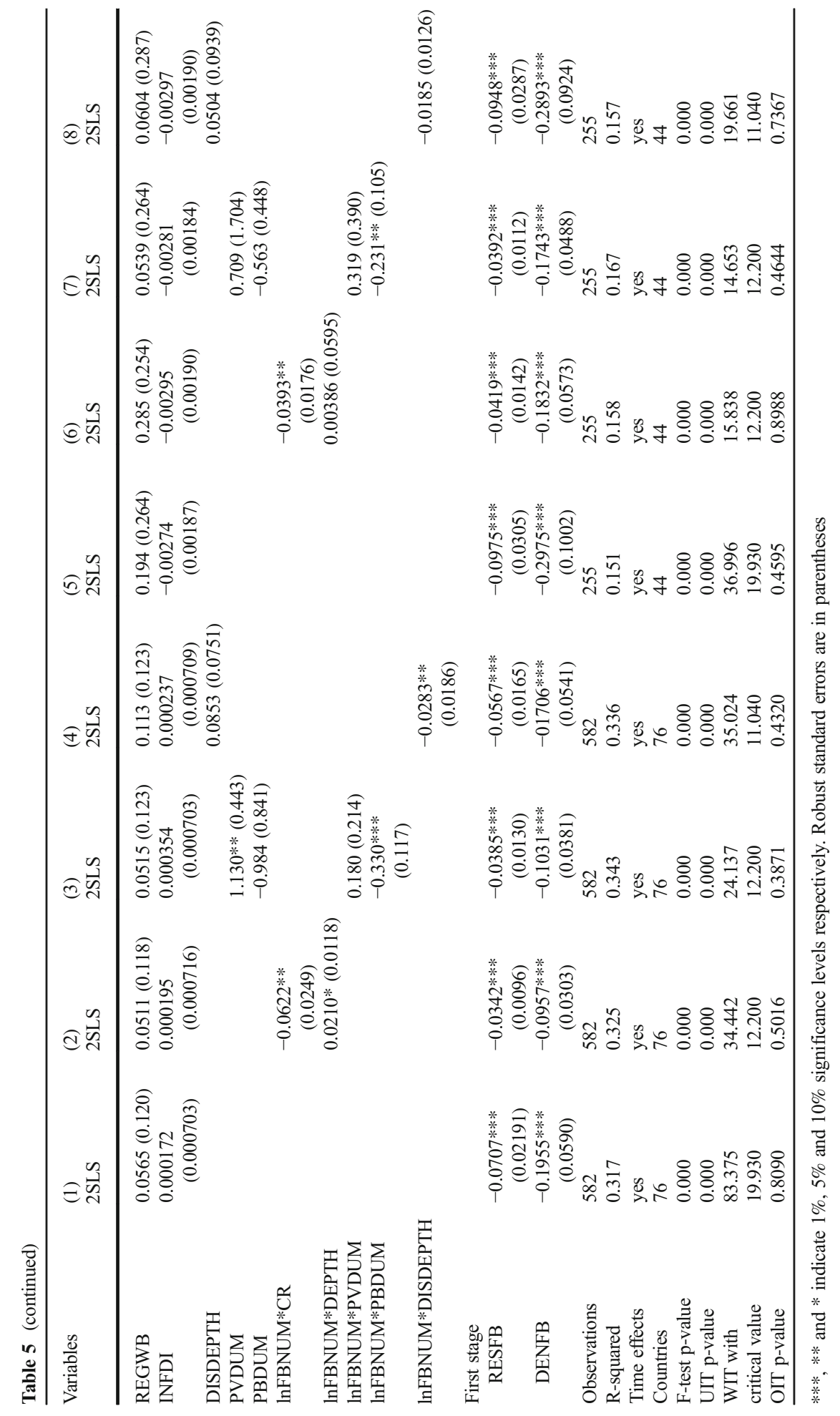


exerts a positive and significant at the $5 \%$ level effect on the two entrepreneurship variables (see models 1-8 in Table 5). This lends further support to hypothesis $H 1 . B$ that foreign bank presence would have a positive effect on new firm entry. Additionally, in further support of hypothesis $H 2 . B$, the interaction term between foreign bank presence and creditor rights ( $\left.\operatorname{lnFBNUM}{ }^{*} \mathrm{CR}\right)$ is negative and exerts significant at the $5 \%$ level effect on the two measures of entrepreneurship we employ (see models 2 and 6 of Table 5). Some support of hypothesis $H 3$ that information sharing would strengthen the positive effect of foreign bank presence on new firm entry is also evident. The interaction term between foreign bank presence (lnFBNUM) and depth of credit information sharing (DEPTH) is positive and significant at the $10 \%$ level in model 2 of Table 5 when the dependent variable is the World Bank measure of entrepreneurship (lnENT). However, it is positive and not significantly different from zero when the dependent variable is the nascent entrepreneurship (lnNascent) measure from GEM (see model 6 of Table 5). We also find further evidence that the positive effect of foreign bank presence on entrepreneurship weakens in the presence of public credit registries. In model 3 and model 7 of Table 5 the interaction term between foreign bank presence and the public credit registry dummy (lnFBNUM*PBDUM) is negative and significant at the $1 \%$ and $5 \%$ level respectively. The latter finding lends additional support to hypothesis $H 4$ that private credit bureaus would be more beneficial than public credit registries in terms of the effect of foreign bank presence on new firm entry. Finally, we find some further evidence that the distance in terms of depth of credit information sharing between the home and host economy (DISDEPTH) weakens the positive effect of foreign bank presence (lnFBNUM) on new firm entry. The interaction term lnFBNUM*DISDEPTH is negative and significant at the $5 \%$ level in model 4 of Table 5 but negative and not significant in model 8 of Table 5 when we use the alternative measure of entrepreneurship (lnNascent) as the dependent variable. The latter finding lends some weak support to hypothesis $H 5$ that distance effects would moderate the positive effect of foreign bank presence on new firm entry. ${ }^{16}$

\subsubsection{Panel VAR estimations}

As a final robustness check, we follow Love and Zicchino (2006) and opt for the flexible framework of a panel VAR specification that includes the new firm entry rate variable (lnENT) and the foreign bank presence variable ( $\operatorname{lnFBAST}$ ). In a panel VAR framework, all variables are assumed to be endogenous and in this way we can take into account reverse causality issues. Furthermore, the panel VAR analysis allows us to observe the isolated impact of foreign bank presence on new firm entry rate as well as its intertemporal effects. Specifically, we focus on orthogonalized impulse-response functions (IRFs), which show the response of the variable of interest (new firm entry) to an orthogonal shock in another variable of interest (foreign bank presence). ${ }^{17}$ By orthogonalizing the response we are able to identify the effect of one shock at a time, while holding other shocks constant. We present the IRFs results in graphical form in Fig. 1. The second graph of the first row shows the response of new firm entry $(\operatorname{lnENT})$ on a

\footnotetext{
${ }^{16}$ We have also estimated 2SLS IV models that include the interaction terms between foreign banks presence and the other distance (proximity) variables (geographic distance, cultural proximity and creditor rights distance), but we did not find statistically significant effects.

${ }^{17}$ As a first step in the panel VAR estimation we follow Lütkepohl (2006) and assume the optimal order of lags for the right-hand side variables of the system of equations. We compute for the first, second and third lag the Arellano-Bond GMM estimator. We confirm with the results of the Akaike Information Criterion (AIC) and with the results of the Arellano-Bond AR tests that the optimal lag is of order one. Furthermore, because we cannot have time effects, variables are time-demeaned to remove unwanted trends.
} 
Impulse-responses for 1 lag VAR of Innewent Infbast
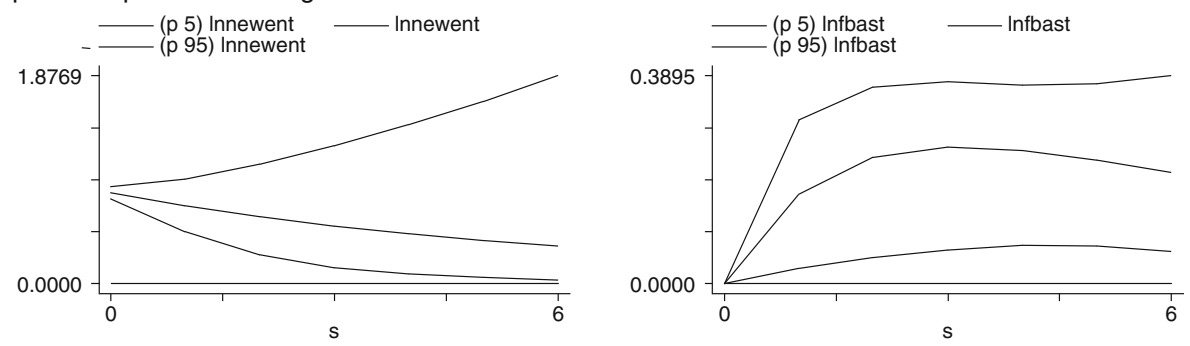

response of Innewent to Innewent shock response of Innewent to Infbast shock
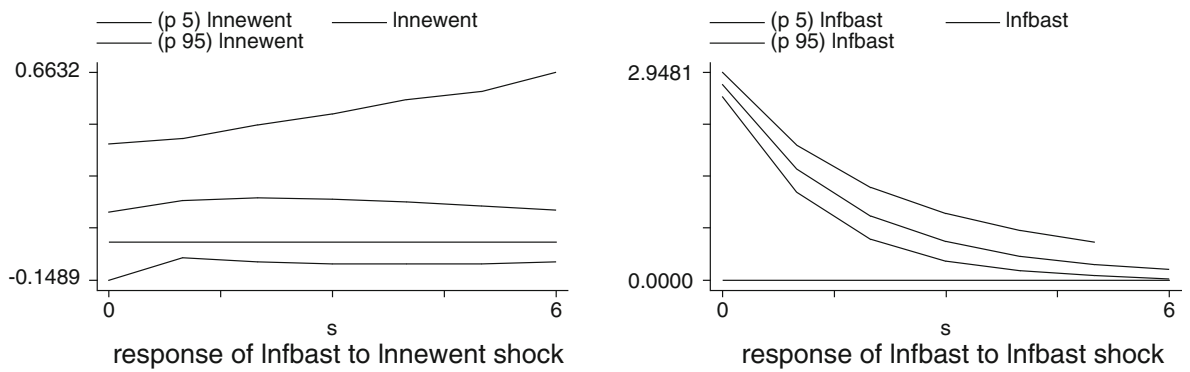

Errors are $5 \%$ on each side generated by Monte-Carlo with 500 reps

Fig. 1 The effect of foreign bank presence on new firm entry -Impulse Response Functions (IRFs) from Panel VAR estimation. Note: lnENT stands for the natural logarithm of new entry density and lnFBAST is the natural logarithm of foreign bank assets over total bank assets

one standard deviation shock of the foreign bank presence variable (lnFBAST). The middle line is the impulse response, and the two lines above and below are the $95 \%$ and $5 \%$ confidence intervals, respectively, obtained from Monte Carlo simulation (we use 500 replications).

In line with hypothesis H1.B, we observe that new firm entry (lnENT) responds positively and significantly (at the 5\% level) to a foreign bank presence (lnFBAST) shock. Furthermore, this is a long-lasting effect implying that the positive effect of foreign bank presence on new firm entry rate persists over time. Box 1 in Table 6 presents further evidence of the importance of foreign bank presence for new firm entry as reported by the variance decompositions (VDCs) estimations. Specifically, around $13.67 \%$ of the forecast error variance of new firm

Table 6 The effect of foreign bank presence on new firm entry and nascent entrepreneurship - Variance Decompositions (VDCs) from Panel VAR estimation. lnENT stands for the natural logarithm of new firm entry density, InNascent is the natural logarithm of nascent entrepreneurship, lnFBAST is the natural logarithm of foreign bank assets over total bank assets. s denotes periods ahead

\begin{tabular}{llllllll}
\hline Box 1 & \multicolumn{7}{c}{ Box 2 } \\
\hline Variables & s & lnENT & lnFBAST & Variables & s & lnNascent & InFBAST \\
lnENT & 10 & 0.8633 & 0.1367 & lnNascent & 10 & 0.7045 & 0.2955 \\
lnFBAST & 10 & 0.0159 & 0.9841 & lnFBAST & 10 & 0.0029 & 0.9971 \\
lnENT & 20 & 0.8524 & 0.1476 & lnNascent & 20 & 0.7041 & 0.2959 \\
lnFBAST & 20 & 0.0176 & 0.9824 & lnFBAST & 20 & 0.0029 & 0.9971 \\
lnENT & 30 & 0.8518 & 0.1482 & lnNascent & 30 & 0.7041 & 0.2959 \\
lnFBAST & 30 & 0.0177 & 0.9823 & lnFBAST & 30 & 0.0029 & 0.9971 \\
\hline
\end{tabular}



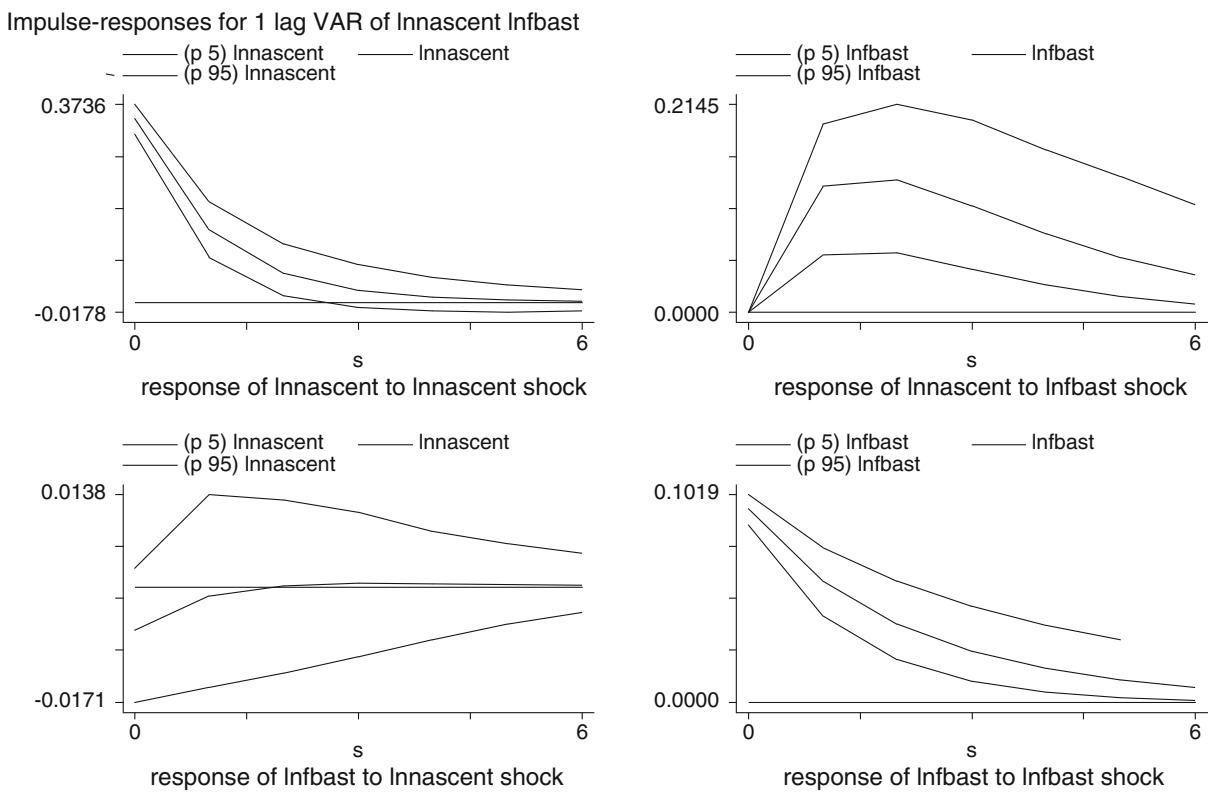

Errors are $5 \%$ on each side generated by Monte-Carlo with 500 reps

Fig. 2 The effect of foreign bank presence on new firm entry -Impulse Response Functions (IRFs) from Panel VAR estimation with alternative measure of entrepreneurship. Note: InNascent stands for the natural logarithm of nascent entrepreneurship and lnFBAST is the natural logarithm of foreign bank assets over total bank assets

entry $(\operatorname{lnENT})$ after 10 years is explained by foreign bank presence (lnFBAST) disturbances. We obtain similar results (See Box 2 in Table 6 and Fig. 2) from the panel VAR specification when we employ the alternative entrepreneurship variable (lnNascent).

\section{Conclusion}

This study finds that foreign bank presence exerts a positive and significant effect on new firm entry. Furthermore, the positive effect of foreign bank presence on new firm entry subdues at higher levels of creditor rights but strengthens at higher levels of information sharing. The former result indicates, from an entrepreneurship standpoint, that foreign bank presence could substitute for weak legal structures in the host economies. The latter finding provides evidence that foreign banks could particularly benefit entrepreneurship when a host economy has in place a strong information sharing infrastructure. This could enable foreign banks to reduce the information asymmetries they face in the host economy by enabling the use of their advanced lending technologies such as credit scoring.

In further analysis, we provide evidence that the information sharing provider matters. More specifically, we find that the positive effect of foreign bank presence on new firm entry strengthens in the presence of a private credit bureau but subdues in the presence of public credit registry. Private credit bureaus, by providing rich information on the credit history of a wide range of potential borrowers, as for example small borrowers, and the provision of additional services such as credit scoring, reduce the information asymmetry between foreign 
banks and the opaque entrepreneurship credit market segment and thus facilitate foreign bank lending to entrepreneurial efforts. Finally, we also provide some evidence that distance between the home and host economies in terms of information sharing and culture weakens the positive effect of foreign bank presence on new firm entry.

These empirical findings have some important policy implications. Governments, especially in countries with weak legal structure, could try to attract foreign bank investment in order to enhance the entrepreneurship rates in their economies. Furthermore, governments in countries where already foreign bank presence is high could focus on improving the information sharing infrastructure of their banking system, especially through private credit bureaus, in order to facilitate foreign bank lending to entrepreneurs.

\section{Appendix 1}

Table 7 Countries included in the analysis. The selection of countries reflects the availability of the dependent and the explanatory variables of the analysis

\begin{tabular}{|c|c|c|c|c|}
\hline Albania & Denmark & Korea, Rep. & Portugal & Uruguay \\
\hline Algeria & Dominican Republic & Kyrgyz Republic & Romania & Uzbekistan \\
\hline Armenia & El Salvador & Latvia & Rwanda & Zambia \\
\hline Australia & Estonia & Lithuania & Senegal & \\
\hline Austria & Finland & Luxembourg & Serbia & \\
\hline Azerbaijan & France & Macedonia, FYR & Singapore & \\
\hline Belarus & Georgia & Mauritius & Slovak Republic & \\
\hline Belgium & Germany & Moldova & Slovenia & \\
\hline Bolivia & Ghana & Mongolia & South Africa & \\
\hline Bosnia and Herzegovina & Greece & Montenegro & Spain & \\
\hline Botswana & Guatemala & Morocco & Sweden & \\
\hline Bulgaria & Hong Kong, China & Namibia & Switzerland & \\
\hline Burkina Faso & Hungary & Nepal & Thailand & \\
\hline Canada & Ireland & Netherlands & Togo & \\
\hline Chile & Israel & New Zealand & Tunisia & \\
\hline Colombia & Italy & Niger & Turkey & \\
\hline Congo, Dem. Rep. & Jamaica & Norway & Uganda & \\
\hline Costa Rica & Jordan & Peru & Ukraine & \\
\hline Croatia & Kazakhstan & Philippines & UAE & \\
\hline Czech Republic & Kenya & Poland & United Kingdom & \\
\hline
\end{tabular}




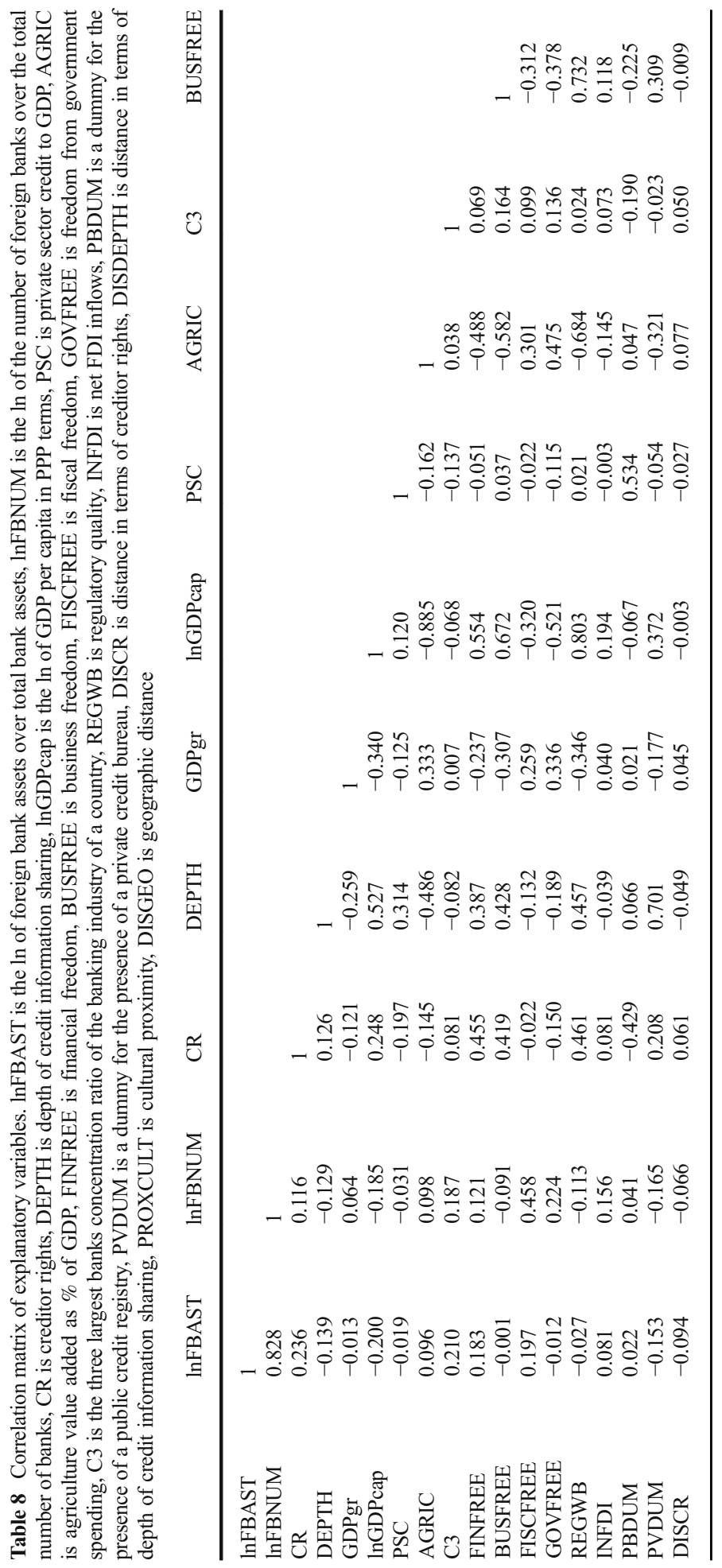




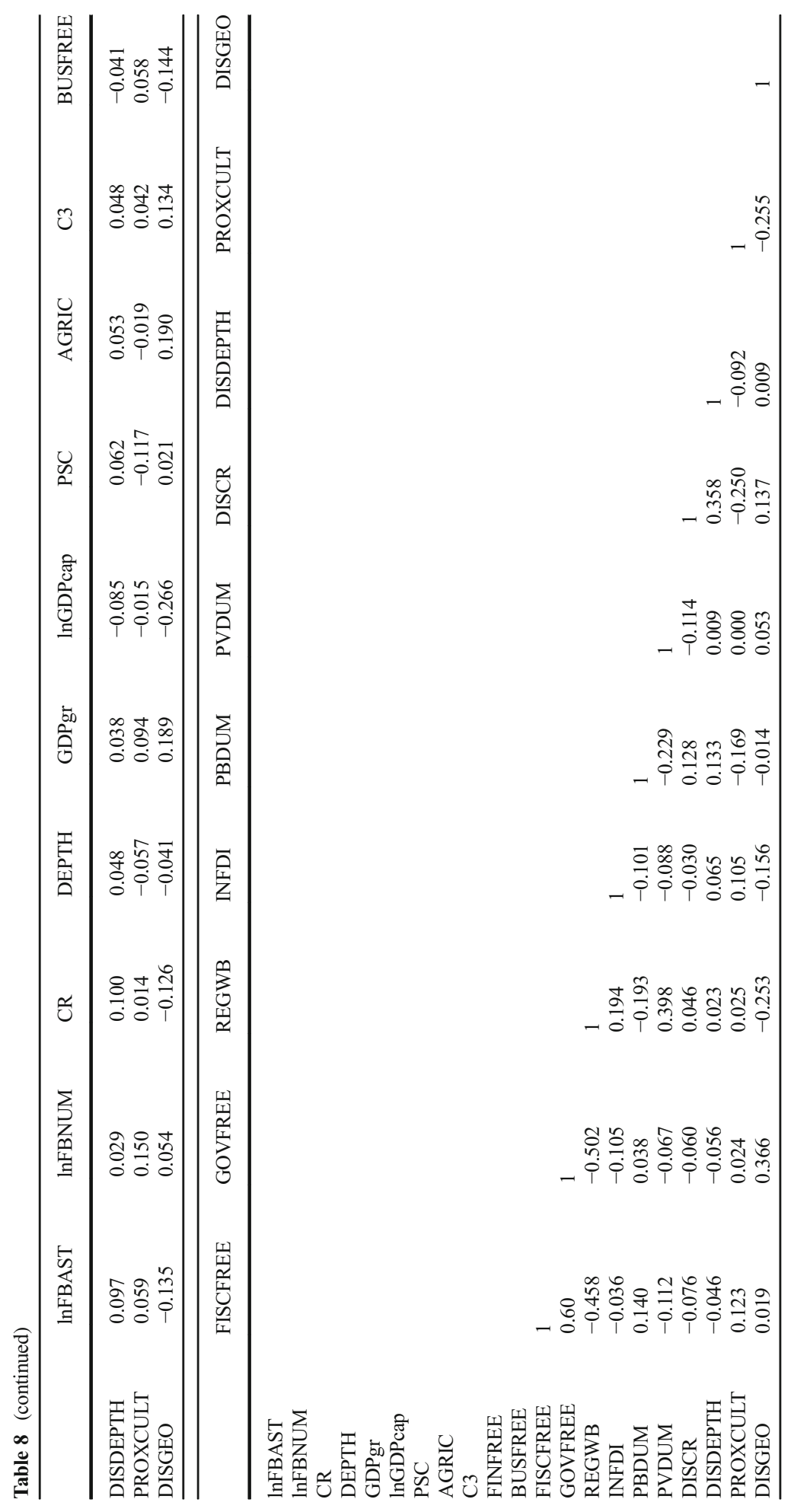




\section{Appendix 3. Additional information on the validity of instrumental variables}

The findings in Table 5 demonstrate that the instrumental variables that measure foreign bank regulatory restrictions (RESFB) and foreign bank denied applications (DENBFB) have a negative and significant at the $1 \%$ level effect on the foreign bank presence variable (lnFBNUM). Here we provide evidence from fixed effect models that these instrumental variables (RESFB and DENFB) do not exert a statistically significant direct effect on our measures of entrepreneurship (lnNewentry and lnNascent). The models in Table A3 include also the other explanatory variables of entrepreneurship that we do not report in this table to economize space. We further validate the weak and not statistically significant relationship between the two instrumental variables and the two measures of entrepreneurships in panel VAR models.

Table 9 The effect of foreign bank regulatory restrictions (RESFB) and foreign bank application denial (DENFB) on entrepreneurship. The dependent variable in model 1 is the natural logarithm of the new firm entry rates (lnENT) from the World Bank Entrepreneurship Database. The dependent variable in model 2 is the natural logarithm of nascent entrepreneurship (lnNascent) from the Global Entrepreneurship Monitor. Both models are estimated with fixed effects

\begin{tabular}{lcc}
\hline Variables & $(1)$ & $(2)$ \\
\hline DENFB & $-0.239(0.191)$ & $-0.0133(0.177)$ \\
RESFB & $0.0487(0.0763)$ & $0.106(0.0927)$ \\
Constant & $-13.69 * * *(2.363)$ & $-5.783(4.405)$ \\
Observations & 582 & 255 \\
F-test $p$-value & 0.000 & 0.000 \\
Time effects & yes & yes \\
R-squared & 0.327 & 0.179 \\
Countries & 76 & 44 \\
\hline
\end{tabular}

$* * *, * *$ and $*$ indicate $1 \%, 5 \%$ and $10 \%$ significance levels respectively. Robust standard errors are in parentheses

\section{References}

Aghion P, Fally T, Scarpetta S (2007) Credit constraints as a barrier to the entry and post-entry growth of firms. Econ Policy 52(4):731-779

Aidis R, Estrin S, Mickiewicz T (2012) Size matters: entrepreneurial entry and government. Small Bus Econ 39(1):119-139

Ardagna S, Lusardi A (2010) The effect of regulation on entrepreneurship: evidence across countries. J Eur Econ Assoc 8(2-3):594-605

Arellano M, Bond S (1991) Some tests of specification for panel data: Monte Carlo evidence and an application to employment equations. Rev Econ Stud 58(2):277-297

Arellano M, Bover O (1995) Another look at instrumental variables estimation of error-component models. J Econ 68(1):29-51

Asiedu E, Lien D (2011) Democracy, foreign direct investment, and natural resources. J Int Econ 84(1):99-111

Avery RB, Bostic RW, Samolyk KA (1998) The role of personal wealth in small business finance. J Bank Financ 22:1019-1061

Baliamoune-Lutz M, Garello P (2014) Tax structure and entrepreneurship. Small Bus Econ 42(1):165-190

Bartelsman EJ, Scarpetta S, Schivardi F (2003) Comparative analysis of firm demographics and survival: microlevel evidence for the OECD countries. OECD economics department working paper no. 348, OECD, Paris

Bartelsman EJ, Haltiwanger J, Scarpetta S (2004) Microeconomic evidence of creative destruction in industrial and developing countries. World Bank policy research working paper 3464

Barth JR, Caprio G Jr, Levine R (2008) Bank regulations are changing: for better or worse? Comp Econ Stud 50(4):537-563

Barth JR, Caprio G Jr, Levine R (2013) Bank regulation and supervision in 180 countries from 1999 to 2011 . J Financ Econ Policy 5(2):111-219

Beck T, Demirgüç-Kunt A, Maksimovic V (2004) Bank competition, financing obstacles and access to credit. J Money Credit Bank 36(3):627-648 
Beck T, Demirgüç-Kunt A, Martínez Pería MS (2011) Bank financing for SMEs: evidence across countries and bank ownership types. J Financ Serv Res 39(1-2):35-54

Beck T, Ioannidou V, Schäfer L (2016) Foreigners vs. natives: Bank lending technologies and loan pricing. Manag Sci forthcoming

Belitski M, Chowdhury F, Desai S (2016) Taxes, corruption, and entry. Small Bus Econ 47(1):201-216

Berger AN, Black LK (2011) Bank size, lending technologies, and small business finance. J Bank Financ 35(3):724-735

Berger AN, Frame WS (2007) Small business credit scoring and credit availability. J Small Bus Manag 45(1):5-22

Berger AN, Udell GF (2002) Small business credit availability and relationship lending: the importance of Bank Organisational structure. Econ J 112(477):32-53

Berger AN, Udell GF (2006) A more complete conceptual framework for SME finance. J Bank Financ 30(11):29452966

Berger A, DeYoung R, Genay H, Udell G (2000) Globalisation of financial institutions: evidence from crossborder banking performance. Brookings-Wharton Papers on Financial Service 3:23-120

Berger AN, Klapper LF, Udell GF (2001) The ability of banks to lend to informationally opaque small businesses. J Bank Financ 25(12):2127-2167

Berger AN, Hasan I, Klapper LF (2004) Further evidence on the link between finance and growth: an international analysis of community banking and economic performance. J Financ Serv Res 25(2-3):169-202

Berger AN, Miller NH, Petersen MA, Rajan RG, Stein JC (2005) Does function follow organizational form? Evidence from the lending practices of large and small banks. J Financ Econ 76(2):237-269

Berger AN, Klapper LF, Martínez Pería MS, Zaidi R (2008) Bank ownership type and banking relationships. J Financ Intermed 17(1):37-62

Berger AN, Frame WS, Ioannidou V (2011) Tests of ex ante versus ex post theories of collateral using private and public information. J Financ Econ 100(1):85-97

Besanko D, Thakor AV (1987) Collateral and rationing: sorting Equalibria in monopolistic and competitive credit markets. Int Econ Rev 28(3):671-689

Bester H (1985) Screening vs. rationing in credit markets with imperfect information. Am Econ Rev 75(4):850-855

Black SE, Strahan PE (2002) Entrepreneurship and bank credit availability. J Financ 57(6):2807-2833

Blundell R, Bond S (1998) Initial conditions and moment restrictions in dynamic panel-data models. J Econ 87(1):115-143

Bonaccorsi di Patti E, Dell'Ariccia G (2004) Bank competition and firm creation. J Money Credit Bank 36(2):225-251

Bond SR (2002) Dynamic panel data models: a guide to micro data methods and practice. Port Econ J 1(2):141-162

Bos JW, De Haas R, Millone M (2016) Show me yours and I'll show you mine: sharing borrower information in a competitive credit market. Baffi Carefin Centre Research Paper, 2015-2018

Branstetter L, Lima F, Taylor LJ, Venâncio A (2014) Do entry regulations deter entrepreneurship and job creation? Evidence from recent reforms in Portugal. The Econ J 124(577):805-832

Braunerhjelm P, Eklund JE (2014) Taxes, tax administrative burdens and new firm formation. Kyklos 67(1):1-11

Brown M, Jappelli T, Pagano M (2009) Information sharing and credit: firm-level evidence from transition countries. J Financ Intermed 18(2):151-172

Brown M, Ongena S, Popov A, Yeșin P (2011) Who needs credit and who gets credit in Eastern Europe? Econ Policy 26(65):93-130

Bruno V, Hauswald R (2014) The real effect of foreign banks. Rev Financ 18(5):1683-1716

Bruno RL, Bychkova M, Estrin S (2013) Institutional determinants of new firm entry in Russia: a cross-regional analysis. Rev Econ Stat 95(5):1740-1749

Bulan L, Yan Z (2009) The pecking order of financing in the Firm's life cycle. Bank Financ Lett 1(3):129-140

Business D (2010) Doing business 2010. World Bank and the international finance corporation. Oxford University Press, Washington DC

Caves RE (1998) Industrial organization and new findings on the turnover and mobility of firms. J Econ Lit 36(4):1947-1982

Cetorelli N, Strahan P (2006) Finance as a barrier to entry: Bank competition and industry structure in local U.S. markets. J Financ 61(1):437-461

Chavis LW, Klapper L, Love I (2011) The impact of the business environment on young firm financing. World Bank Econ Rev 25(3):448-455

Claessens S, Van Horen N (2012) Being a foreigner among domestic banks: asset or liability? J Bank Financ 36(5):1276-1290

Claessens S, Van Horen N (2014a) Foreign banks: trends and impact. J Money Credit Bank 46(1):295-326

Claessens S, Van Horen N (2014b) Location decisions of foreign banks and competitor remoteness. J Money Credit Bank 46(1):145-170

Claessens S, Van Horen N (2015) The impact of the global financial crisis on banking globalization. IMF Economic Review 63(4):868-918 
Clarke G, Cull R, Martínez Pería MS, Sánchez SM (2001) Foreign Bank entry: experience, implications for developing countries, and agenda for further research. World Bank policy research working paper no. 2698

Clarke G, Cull R, Martínez Pería MS, Sánchez SM (2002) Bank lending to small businesses in Latin America. WB Policy Research Working Paper, no. 2760

Clarke G, Cull R, Martínez Pería MS, Sánchez SM (2005) Bank lending to small businesses in Latin America: does bank origin matter? J Money Credit Bank 37:83-118

Cohen WM, Klepper S (1992) The anatomy of Industry R\&D Intensity Distributions. Am Econ Rev 82(4):773-788

Cull R, Martínez Pería MS (2013) Bank ownership and lending patterns during the 2008-2009 financial crisis: evidence from Latin America and Eastern Europe. J Bank Financ 37(12):4861-4878

Cullen J, Gordon RH (2007) Taxes and entrepreneurial risk-taking: theory and evidence for the U.S. J Public Econ 91(7-8):1479-1505

Da Rin M, Di Giacomo M, Sembenelli A (2011) Entrepreneurship, firm entry, and the taxation of corporate income: evidence from Europe. J Public Econ 95(9-10):1048-1066

De Haas R, Naaborg I (2006) "Foreign banks in transition countries: to whom do they lend and how are they financed?", financial markets. Institutions Instruments 15(4):159-199

De Haas R, Van Lelyveld I (2006) Foreign banks and credit stability in central and Eastern Europe: friends or foes? J Bank Financ 30(7):1927-1952

De Haas R, Van Horen N, Zettelmeyer J (2010) Running for Exit: International Banks and Crisis Transmission. mimeo

De la Torre A, Martínez Pería MS, Schmukler SL (2010) Bank involvement with SMEs: beyond relationship lending. J Bank Financ 34(9):2280-2293

Degryse H, Havrylchk O, Jurzyk E, Kozak S (2012) Foreign bank entry, credit allocation and lending rates in emerging markets: empirical evidence from Poland. J Bank Financ 36(12):2949-2959

Delis M, Hasan I, Mylonidis N (2016) Foreign Bank ownership and income inequality: empirical evidence. Fordham Univeristy, Working Paper

Dell'Ariccia G, Marquez R (2004) Information and Bank credit allocation. J Financ Econ 72(1):185-214

Dell'Ariccia G, Marquez R (2006) Lending booms and lending standards. J Financ 61(5):2511-2546

Demirguç-Kunt A, Love I, Maksimovic V (2006) Business environment and the incorporation decision. J Bank Financ 30(11):2967-2993

Detragiache E, Gupta P, Tressel T (2008) Foreign banks in poor countries: theory and evidence. J Financ 63(5):2123-2160

Dierkes M, Erner C, Langer T, Norden L (2013) Business credit information sparing and default risk of private firms. J Bank Financ 37(8):2867-2878

Djankov S, La Porta R, Lopez-de-Silanes F, Shleifer A (2002) The regulation of entry. Q J Econ 117(1):1-35

Djankov S, McLiesh C, Shleifer A (2007) Private credit in 129 countries. J Financ Econ 84(2):299-329

Doblas-Madrid A, Minetti R (2012) Sharing information in the credit market: contract-level evidence from U.S. firms. J Financ Econ 109(1):198-223

Dreher A, Gassebner M (2013) Greasing the wheels? The impact of regulations and corruption on firm entry. Public Choice 155(3-4):413-432

Dutta N, Sobel R (2016) Does corruption ever help entrepreneurship? Small Bus Econ 47(1):179-199

Feldman R (1997) Small business loans. Small Banks and a Big Change in Technology Called Credit Scoring. Federal Reserve Bank of Minneapolis' The Region, September, pp 19-25

Frame WS, Woosley L (2004) Credit scoring and the availability of small business credit in low-and moderateincome areas. Financ Rev 39(1):35-54

Fratzscher M, König PJ, Lambert C (2016) Credit provision and banking stability after the great financial crisis: the role of bank regulation and the quality of governance. J Int Money Financ 66(1):113-135

Gianetti M, Ongena S (2012) Lending by example: direct and indirect effects of foreign banks in emerging markets. J Int Econ 86(1):167-180

Giannetti M, Ongena S (2009) Financial integration and firm performance: evidence from foreign bank entry in emerging markets. Rev Finance 13(2):181-223

Giannetti M, Liberti J, Sturgess J (2016) Information sharing and rating manipulation. Working paper, Stockholm School of Economics

Godlewski CJ, Weill L (2011) Does collateral help mitigate adverse selection? A cross-country analysis. J Financ Serv Res 40(1-2):49-78

Gormley TA (2010) The impact of foreign bank entry in emerging markets: evidence from India. J Financ Intermed 19(1):26-51

Grajzl P, Laptieva N (2016) Information sharing and the volume of private credit in transition: evidence from Ukrainian bank-level panel data. J Comp Econ 44(2):434-449

Haselmann R, Pistor K, Vig V (2010) How law affects lending. Rev Financ Stud 23(2):549-580

Havrylchyk O (2012) The effect of foreign bank presence on firm entry and exit in transition economies. J Bank Financ 36(6):1710-1721 
Houston JF, Lin C, Lin P, Ma Y (2010) Creditor rights, information sharing, and bank risk taking. J Financ Econ 96(3):485-512

Jappelli T, Pagano M (2002) Information sharing, lending and defaults: cross-country evidence. J Bank Financ 26(10):2017-2045

Kallberg JG, Udell GF (2003) The value of private sector business credit information sharing: the US case. J Bank Financ 27(3):449-469

Klapper LF, Love I (2011a) Entrepreneurship and development: the role of information asymmetries. World Bank. Econ Rev 25(3):448-455

Klapper L, Love I (2011b) The impact of the financial crisis on new firm registration. Econ Lett 113(1):1-4

Klapper L, Love I (2014) The impact of business environment reforms on new registrations of limited liability companies. World Bank Econ Rev 30(2):332-353

Klapper L, Laevena L, Rajan R (2006) Entry regulation as a barrier to entrepreneurship. J Financ Econ 82(3):591-629

Klapper L, Amit R, Guillen M (2010) Entrepreneurship and firm formation across countries. In: Joshua Lerner and Antoinette Shoar (ed) international differences in entrepreneurship. University of Chicago Press, Chicago

Klapper L, Love I, Randall D (2015) New firm registration and the business cycle. Int Entrep Manag J 11(2): 287-306

Klein DB (1992) Promise keeping in the great society: a model of credit information sharing. Econ Polit 4(2):117-136

Kouretas GP, Tsoumas C (2016) Foreign bank presence and business regulations. J Financ Stab 24:104-116

Liberti JM, Mian AR (2009) Estimating the effect of hierarchies on information use. Rev Financ Stud 22(10):4057-4090

Love I, Mylenko N (2003) Credit reporting and financing constraints. World Bank policy research working paper 3142

Love I, Zicchino L (2006) Financial development and dynamic investment behavior: evidence from panel VAR. Q Rev Econ Financ 46(2):190-210

Love I, Martínez Pería MS, Singh S (2016) Collateral registries for movable assets: does their introduction spur firms' access to Bank financing? J Financ Serv Res 49(1):1-37

Lütkepohl H (2006) New introduction to multiple time series analysis. Springer, Berlin

Martínez Pería MS and Singh S (2014) The impact of credit information sharing reforms on firm financing?. World Bank policy research working paper 7013

Mester L (1997) What's the point of credit scoring?. Federal Reserve Bank of Philadelphia Business Review, pp 3-16

Mian A (2006) Distance constraints: the limits of foreign lending in poor economies. J Financ 61(3):1465-1505

Moon J (2009) Small business finance and personal assets. Community Investments 39(3):9-10

Nickell S (1996) Competition and corporate performance. J Polit Econ 104(4):724-746

OECD (2010) Facilitating access to finance. Discussion Paper on Credit Information Sharing

Ongena, S., Popov, A. and Udell, G.F. (2013), When the cat's away the mice will play: does regulation at home affect bank risk-taking abroad?, J Financ Econ, 108(3), 727-750

Padilla JA, Pagano M (1997) Endogenous communication among lenders and entrepreneurial incentives. Rev Financ Stud 10(1):205-236

Padilla JA, Pagano M (2000) Sharing default information as a borrower discipline device. Eur Econ Rev 44(10): 1951-1980

Pagano M, Jappelli T (1993) Information sharing in credit markets. J Financ 43(5):1693-1718

Pennathur A, Vishwasrao S (2014) The financial crisis and bank-client relationships: foreign ownership, transparency, and portfolio selection. J Bank Financ 42(5):232-246

Robb AM, Robinson DT (2013) The capital structure decisions of new firms. Rev Financ Stud 27(1):153-179

Roodman D (2009) A note on the theme of too many instruments. Oxf Bull Econ Stat 71(1):135-158

Schmalz MC, Sraer DA, Thesmar D (2013) Housing collateral and entrepreneurship. National Bureau of economic research working paper 19680

Sengupta R (2007) Foreign entry and Bank competition. J Financ Econ 84(2):502-528

Siemer M (2014-2056) (2014) firm entry and employment dynamics during the great recession. FEDS Working paper, Federal Reserve Board

Stein JC (2002) Information production and capital allocation: decentralized versus hierarchical firms. J Financ 57(5):1891-1921

Stock JH, Yogo M (2005) Testing for weak instruments in linear IV regression. Identification and inference for econometric models: Essays in honor of Thomas Rothenberg, chap 5, pp 80-108

Tsai H, Chang Y, Hsiao PH (2011) What drives foreign expansion of the top 100 multinational banks? The role of credit reporting system. J Bank Financ 35(3):588-605

Wennekers S, van Stel A, Thurik R, Reynolds P (2005) Nascent entrepreneurship and the level of economic development. Small Bus Econ 24(3):293-309

Windmeijer F (2005) A finite sample correction for the variance of linear efficient two-step GMM estimators. J Econ 126(1):25-51

World Bank (2014) International committee on credit reporting: facilitating SME financing through improved credit reporting. World Bank Group, Washington, DC 